\title{
LIETUVOS KARIUOMENĖS IŠVEDIMAS IŠ KLAIPĖDOS KRAŠTO (1939 M.)
}

\author{
Dr. Vytautas Jokubauskas \\ Klaipedos universiteto Baltijos regiono istorijos ir \\ archeologijos instituto mokslo darbuotojas
}

Klaipėdos, kaip ir Vilniaus, krašto priklausomybès tarpukariu problemos yra ir ateityje, matyt, liks aktualios ne tik kaip akademinio tyrimo, bet ir kaip politinių diskusijų objektas. Istorikai ị tuos pačius praeities ịvykius kaskart pažvelgia vis kitu kampu, atskleisdami naujus ar verifikuodami ir aktualiai interpretuodami seniai žinomus istorijos faktus, neretai pateikdami originalių įžvalgų. Kita vertus, politiniame diskurse kaimyninès šalys vis dar manipuliuoja Klaipėdos priklausymo Lietuvai legitimumu. Svarbus ir trečias - karinio planavimo ir karinių pajegų reagavimo - klausimas: kaip Lietuvos kariuomenè tarpukariu gebejo reaguoti $\mathfrak{j}$ krizes, kritines situacijas. Istoriko Šarūno Liekio teigimu, „Klaipedos ịvykiai buvo pirmoji krizè, kurių masto ir pasekmių Lietuvos politinė ir karinè vadovybė negalèjo aiškiai prognozuoti. <...> Kariuomenès modernizavimo programa, pradèta 1935 m., iš esmès neišsprendè kariuomenès parengties ir modernizavimo problemų. <...> Esminiai trukdžiai buvo susiję su lètu planavimu, koordinacijos stoka, lètai perduodama informacija ir neaiškia subordinacija“"

Svarbūs XXI a. pradžios karybos pokyčiai karo istorikams atveria daugybę galimybių naujai pažvelgti ị ịvairias akademines problemas, kurios daugiau ar mažiau, vienu ar kitu aspektu jau buvo analizuotos. Aiškẻja, kad gyventojų požiūris ir laikysena turi didžiulę ịtaką galimybei apginti teritoriją, o tam tikrais atvejais netgi yra lemiamas veiksnys². Karybos te-

\footnotetext{
1 Liekis, Š. 1939 m. Vokietijos karinè agresija ir Lietuvos galimybès valdyti karinę krizę. Klaipèdos krašto aneksija 1939 m.: politiniai, ideologiniai, socialiniai ir kariniai aspektai (Acta Historica Universitatis Klaipedensis, t. XXI). Sud. S. Pocytè. Klaipėda, 2010, p. 111. 2 Jokubauskas, V.; Vaičenonis, J.; Vareikis, V.; Vitkus, H. Valia priešintis: paramilitarizmas ir Lietuvos karinio saugumo problemos. Klaipėda, 2015, p. 252-255; Jokubauskas, V.
} 
oretiku pateikta hibridinio karo (angl. Hybrid warfare) koncepcija verčia permąstyti nemažai karo istorijos epizodų: vien XX a. tai - 1919 m. kovos su bermontininkais, 1920 m. gen. Liucjano Želigovskio žygis, 1923 m. Lietuvos kariné operacija Klaipėdoje ir 1939 m. Vokietijos veiksmai prieš Lietuvą, Klaipėdos krašto užgrobimas, pagaliau 1940 m. sovietinė okupacija. Pastarosios dvi, Vokietijos ir SSRS, karinès operacijos prieš Lietuvą puikiai atitinka Sun Tzu mokymą: „Karas - tai apgavystès kelias <...> kautis mūšiuose ir šimtą kartų laimėti - nèra meistriškumo viršūnè. Pavergti priešo kariauną be kovos - štai tikra meistriškumo viršūnè. “3 Minètos operacijos atitinka ir britų karybos teoretiko kpt. Basilio Henrio Liddellio Harto netiesioginiu veiksmu strategijos koncepciją, kurios tikslas - susilpninti priešininką dar iki to momento, kai bus siekiama ji itveikti ${ }^{4}$. O Lietuvos karo istorijos tyrimų kontekste 1939 m. ir 1940 m. Vokietijos ir SSRS agresija prieš Lietuvą - klasikiniai pavyzdžiai, todèl jų tyrimai lieka aktualūs ir akademinei bendruomenei, ir visuomenei, ir Lietuvos kariuomenei.

Istoriografijoje 1939 m. Klaipèdos krašto netekimo ir Lietuvos kariuomenès išvedimo problemos analizuotos, bene plačiausiai šias temas nagrinejo Klaipėdos universiteto mokslininkai Vytautas Žalys, Arūnė Liucija Arbušauskaitè, Vygantas Vareikis ir kt. ${ }^{5}$ Tačiau stokojama daugiapjūvio ty-

2014 m. lapkričio 21 d. tarptautinèje konferencijoje „Pilietinė gynyba hibridiniame kare“ skaitytas pranešimas „Teritorinė Lietuvos gynyba: XX a. patirtys atsakant ị XXI a. iššūkius" <https://www.youtube.com/watch?v=G8SzWXf5Tw4>.

3 Sun Tzu. Karo menas. Kaunas, 2007, p. 17, 31.

4 Лиддел Гарт, Б. Стратегия непрямых действий. Москва, 2012, с. 14-16.

5 Žalys, V. Kova dèl identiteto. Kodèl Lietuvai nesisekè Klaipėdoje tarp 1923-1939 m. Lüneburg, 1993; Arbušauskaitè, A. Lietuvos optantai: klaipėdiškiai, 1939. Klaipėda, 2001; Arbušauskaitė, A. L. Anšliusas ir Klaipėdos krašto gyventojai (1939-1944). Klaipėda, 2010; Vareikis, V. Klaipėdos krašto praradimas: tarp iliuzijų ir Realpolitik. Kultūros barai, 2009, Nr. 3 (532), p. 68-75; 2009, Nr. 4 (533), p. 63-69; Vareikis, V. Klaipėdos krašto užèmimas: dokumentai prieš mitus. Kultūros barai, 2009, Nr. 2 (531), p. 63-69; Vareikis, V. Politiniai ir kariniai Klaipėdos krašto praradimo aspektai 1938-1939 metais. Klaipédos krašto aneksija 1939 m.: politiniai, ideologiniai, socialiniai ir kariniai aspektai (Acta Historica Universitatis Klaipedensis, t. XXI). Sud. S. Pocytė. Klaipėda, 2010, p. 69-84; Safronovas, V. „Memelenderių“ daryba, arba ideologinis 1939 m. Klaipėdos krašto aneksijos parengimas. Klaipèdos krašto aneksija 1939 m.: politiniai, ideologiniai, socialiniai ir kariniai aspektai (Acta Historica Universitatis Klaipedensis, t. XXI). Sud. S. Pocytė. Klaipèda, 2010, p. 32-68; Jokubauskas, V. Lietuvos kariuomenès parengti Klaipėdos krašto gynimo planai ir realybė 1939 metais. Klaipédos krašto aneksija 1939 m.: politiniai, ideologiniai, so- 
rimo, aprèpiančio gyventojų sudèties, nuotaikų, politinių krašto praradimo aplinkybių ir kariuomenès reagavimo ị krizę, taip pat dalinių išvedimo aspektus, nes 1939 m. kovo ịvykiai nebuvo netikètas posūkis, o greičiau 16 metų Lietuvos „kovos“ dèl vienintelio uosto epilogas. Pabrèžtina ir o greičiau, kad yra įsigalejusi nuostata, jog 1939 m. kovą Lietuvos kariuomené vangiai reagavo ị krizę, buvo sutrikusi, tvyrojo chaosas, bet nauji archyviniai duomenys verčia tuo abejoti.

Taigi, atsižvelgiant ị minètas aplinkybes, tyrimo tikslas - išanalizuoti 1939 m. kovo mèn. Lietuvos kariuomenès išvedimo iš Klaipėdos krašto ypatumus reaguojant ị po Vokietijos ultimatumo kilusią saugumo krizę. Siekiant šio tikslo bus apibūdinta tautinè ir politinè krašto padètis tarpukariu, aptarta Lietuvos valstybès ir dalies Klaipėdos krašto gyventojų permanentinè konfrontacija, Vokietijos ultimatumo pateikimo aplinkybès ir Lietuvos kariuomenès dalinių veiksmų eiga 1939 m. kovą.

\section{ITAMPOS IR NEPASITIKE்JIMO METAI}

Politinè Klaipėdos krašto vidaus padètis ir vietos gyventojų požiūris ì Lietuvos Respubliką šio pajūrio krašto galimos karinès gynybos perspektyvas komplikavo. 1923 m. prijungus Klaipedos kraštą prie Lietuvos ${ }^{6}$, vietos gyventojai nebuvo itin optimistiškai nusiteikę Lietuvos valstybès atžvilgiu. Prieš Pirmąjị pasaulinị karą, 1910 m., asmenys, kurių gimtoji kalba

cialiniai ir kariniai aspektai (Acta Historica Universitatis Klaipedensis, t. XXI). Sud. S. Pocytè. Klaipėda, 2010, p. 85-103; Jokubauskas, V. Lietuvos trispalvė virš kareivinių. Kareivinès, tapusios Klaipėdos universitetu: studija, skirta Klaipédos universiteto Baltijos regiono istorijos ir archeologijos instituto 20-mečiui, Klaipédos universiteto 20-mečiui ir Klaipédos miesto 760-mečiui. Sud. V. Safronovas. Klaipèda, 2012, p. 71-127.

6 Išsamiau žr.: Vareikis, V. Klaipėdos krašto užèmimas. 1923 metų sausio įvykiai Klaipédoje (Acta Historica Universitatis Klaipedensis, t. IV). Klaipèda, 1995, p. 35-40; Vareikis, V. Dèl „lango ị platųji pasaulị“: Lietuvos šaulių sąjunga 1923 metų Klaipėdos sukilimo metu. Lietuvos šaulių sajunga: praeitis, dabartis, ateitis. Leidinys, skirtas Lietuvos šauliu sajungos gyvavimo 90-mečiui. Sud. R. Varsackytè. Kaunas, 2009, p. 57-76. 
buvo tik lietuvių, sudare $47,53 \%^{7}$, o $1925 \mathrm{~m}$. gyventojų surašymo metu vos 26,56 \% nurodè esą lietuviai, 24,24 \% - „memelenderiai“, 45,28 \% vokiečiai. Naujos grupès atsiradimas verčia ieškoti tokio gyventojų tapatybès pokyčio priežasčių ir sudaro galimybes tai įvairiai interpretuoti, teigti, kad vokiečiai sudare 69,5\% arba lietuviai (pridejjus „memelenderius“ - „klaipèdiečius“) - $51 \%$ krašto gyventojų, ir tuo grịsti didesnes savo teises $^{8}$. Tačiau prolietuviškas nuostatas, arba jų menkumą, atskleidžia ir rinkimų i Klaipėdos krašto seimelị rezultatai, kai lietuviai pagal sąrašus negaudavo daugiau kaip 5 vietų iš $29^{9}$, o paskirais metais mandatų skaičius svyruodavo nuo 2 iki 4-5, taigi dominavo vokiškos partijos, visada surinkdavusios per $80 \%$ rinkèjų balsų ${ }^{10}$. Klaipèdos krašte gyvenusius Prūsijos ir Didžiosios Lietuvos lietuvius siejo tik bendra kalba, o kultūra ir religija buvo skiriamosios dimensijos. Be to, ne mažiau svarbu buvo ir tai, kad šios dvi lietuviškai kalbančios bendruomenès neturëjo apčiuopiamos, abiejų bendruomenių narių įsisąmonintos bendros praeities. Tad Lietuvos kariuomenei ginti kraštą, kurio dauguma vietos gyventojų net nenorejjo būti „apginti“, buvo sunkiai ịvykdoma misija. 1923 m. net Lietuvos kariuomenès karininkai Klaipėdos krašto prijungimo nelaikè Tẻvynès gynimu ${ }^{11}$.

1923 m. balandžio 6-11 d. ịvyko vienas nemaloniausių XX a. 3-iojo dešimtmečio incidentų Klaipėdoje - vietos gyventojų streikas ${ }^{12}$. Balandžio 8 d. Smelteje susirinkusios apie 9000 žmonių minios išvaikyti buvo pasiųsta Lietuvos kariuomenè, o radikaliai nusiteikę gyventojai Lietuvos kariams šaukè: „Szameiten, raus!“13

7 Vileišis, V. Tautiniai santykiai Mažojoje Lietuvoje ligi Didžiojo karo. Istorijos ir statistikos šviesoje su 3 žemélapiais. Vilnius, 2009, p. 190-191.

8 Išsamiau apie „memelenderių“, arba klaipėdiškių, tapatybę žr.: Safronovas, V. „Memelenderių“ daryba, arba ideologinis 1939 m. Klaipėdos krašto aneksijos parengimas. Klaipédos krašto aneksija 1939 m.: politiniai, ideologiniai, socialiniai ir kariniai aspektai (Acta Historica Universitatis Klaipedensis, t. XXI). Sud. S. Pocytè. Klaipèda, 2010, p. 32-68.

9 Žalys, V. Kova dèl identiteto. Kodèl Lietuvai nesiseké Klaipédoje tarp 1923-1939 m. Lüneburg, 1993, p. 8.

10 Žostautaite, P. Klaipédos kraštas 1923-1939. Vilnius, 1992, p. 70-71.

11 Žalys, V. Kova dèl identiteto. Kodèl Lietuvai nesiseké Klaipédoje tarp 1923-1939 m. Lüneburg, 1993, p. 27.

12 Ten pat, p. 40.

13 Černius, [J]. Dvylika metų Klaipedoje. Karys, 1977, sausis, Nr. 1 (1528), p. 2-3; Lie- 
1924 m. rugpjūčio 2 d. Lietuvos vyriausiasis kariuomenès štabas 7-ojo péstininkų pulko vadą plk. ltn. Petrą Genį telegrama informavo, kad rengiamas jo vadovaujamo pulko užpuolimas ${ }^{14}$. Pulko vadas pranešè, kad vietos gyventojai planuoja sukilti naktị iš rugpjūčio $4 \mathrm{~d}$. ị $5 \mathrm{~d}$. ir pirmiausia pulti Klaipedos kareivines. Sužinojus apie sukilimo vadų susirinkimo vietą, rugpjūčio 2-osios naktị vienuolika jų buvo suimta su įkalčiais ${ }^{15}$. Spaudoje teigta, kad sukilèliai (apie 400 vyrų), vadovaujami buvusio Vokietijos kariuomenès feldfebelio Friedricho Blumenau, Klaipèdos kareivines planavo pulti 1.00-2.00 val. nakties ${ }^{16}$. 1924 m. rugpjūčio 4 d. Vyriausiasis štabas III karo apygardos viršininką informavo, kad vietos gyventojų sukilimas Klaipẻdos krašte vèl gali kilti rugpjūčio $23-25$ d. ${ }^{17} 1924$ m. pabaigoje Lietuvos kariuomenès vyriausiasis štabas vèl informavo 7-ojo pėstininkų pulko vadą, kad Kalèdų lakotarpiu vietos vokiečiai arba komunistai gali bandyti surengti „pučą ${ }^{18}$. Gruodžio 30 d. pulko vadas pranešè, kad, jo turimomis žiniomis, naktị vokiečiai ketina pulti Šilutès igulą, bet ši tam jau yra pasirengusi ${ }^{19}$. Vyriausiasis štabas nedelsdamas davẻ nurodymus parengti 5-ajji pèstininkų pulką vykti ị Klaipėdą ${ }^{20}$, buvo sudarytas pulko išvykimo planas $^{21}$. Vis dèlto kitą dieną plk. ltn. P. Genys pranešè, kad „nieko neįvyko“22.

Viena iš Lietuvos kariuomenès štabo ịvardytų grèsmių Klaipẻdos krašte buvo separatistiškai nusiteikusių vietos gyventojų sukilimas, tad $1927 \mathrm{~m}$.

tuvos kariuomenės karo veiksmų su lenkais dienynas, 1922-1923 m. LCVA, f. 929, ap. 3, b. 360, apv. 1. 160 .

14 Vyriausiojo štabo telegrama, 1924 m. rugpjūčio 2 d. LCVA, f. 929, ap. 3, b. 460, 1. 2.

15 III apygardos štabo telefonograma kariuomenès vadui, $1924 \mathrm{~m}$. rugpjūčio $2 \mathrm{~d}$. LCVA, f. 929 , ap. 3 , b. $460,1.3$.

16 Oficialiniai daviniai apie ruoštąji sukilimą Klaipèdoj. Lietuva, 1924 m. rugpjūčio 21, Nr. 187 (1688), p. 2.

17 Vyriausiojo štabo įsakymas III karo apygardos viršininkui, $1924 \mathrm{~m}$. rugpjūčio $4 \mathrm{~d}$. LCVA, f. 929, ap. 3, b. 460, 1. 10-11.

18 Vyriausiojo štabo įsakymas 7-ojo PP vadui, 1924 m. gruodžio 6 d. LCVA, f. 929, ap. 3, b. $460,1.110$.

19 7-ojo PP vado telegrama, 1924 m. gruodžio 30 d. LCVA, f. 929, ap. 3, b. 460, 1. 113.

20 Vyriausiojo štabo įsakymas kariuomenès intendantui, 1924 m. gruodžio $30 \mathrm{~d}$. LCVA, f. 929 , ap. 3, b. $460,1.115$.

21 5-ojo PP išvykimo iš Kauno tvarka, 1924 m. gruodžio 31 d. LCVA, f. 929, ap. 3, b. 460, 1. 117.

22 7-ojo PP vado telegrama, 1924 m. gruodžio 31 d. LCVA, f. 929, ap. 3, b. 460, 1. 116. 
kovo 15 d. buvo parengtas sukilimo malšinimo planas. $1931 \mathrm{~m}$. Kariuomenès štabas papildomai nurodè kariuomenei padèti malšinti neramumus tuo atveju, jei policija ir šauliai to padaryti nepajègtų. Praradus ryši su karine vadovybe, buvo ịsakyta veikti savo nuožiūra. Grèsme buvo laikomi ir vietos komunistai, kurie galejo organizuoti neramumus ${ }^{23}$, buvo parengtas ir Klaipedos miesto gynybos planas ${ }^{24}$. Daugumai Klaipėdos krašto vokiečių, kurie vadovavosi šūkiu „Nemunas yra mūsų upè, bet ne mūsų siena“, naujoji padètis atrodè laikina. Klaipèdos priklausymas Lietuvai atrodè kaip didžiausia istorinè neteisybė. Taigi 1923 m., prijungus Klaipėdą prie Lietuvos, prasidejo penkiolika metų trukusi kova, ir tai atsispindejjo beveik visose krašto gyvenimo srityse $\mathrm{e}^{25}$. O $1931 \mathrm{~m}$. net sklido gandai apie Lietuvos valdžios planus Klaipėdoje surengti perversmą, pasitelkus šaulius, paleisti direktoriją ir galutinai prijungti kraštą prie Lietuvos, nors lietuviški šaltiniai aiškiai neatskleidžia tikrųjų vyriausybės planų šiuo klausimu ${ }^{26}$. Itampą krašte, taip pat tarp Lietuvos ir Vokietijos sukèle 1934-1935 m. Ernsto Neumanno ir Theodoro Sasso procesas ${ }^{27}$.

Iš Lietuvos atvykę kariai ir civiliai persikèlèliai Klaipèdoje susidūrè su realybe - isitikino, kad tai - vokiškas miestas, kuriame „viskas vokiška. Gatvių, krautuvių pavadinimai, užrašai vokiški. Gatvėse girdejjosi tik vokiečių kalba“. Kilo klausimas: „kur gi lietuviai?“, nes „žmonių apsirengimas kitoks, laikysena nedraugiška, mums svetima. Nelietuviška! Pagaliau

23 İsakymas Klaipedos ir Šilutės iguloms: Komunistų arba vokiečių sukilimui malšinti planas, $1931 \mathrm{~m}$. vasario 7 d. LCVA, f. 929, ap. 3, b. 778, 1. 9.

24 Plačiau žr.: Jokubauskas, V. Lietuvos kariuomenès parengti Klaipėdos krašto gynimo planai ir realybė 1939 metais. Klaipédos krašto aneksija 1939 m.: politiniai, ideologiniai, socialiniai ir kariniai aspektai (Acta Historica Universitatis Klaipedensis, t. XXI). Sud. S. Pocytè. Klaipèda, 2010, p. 85-103.

25 Žalys, V. Kova dèl identiteto. Kodèl Lietuvai nesiseké Klaipédoje tarp 1923-1939 m. Lüneburg, 1993, p. 36.

26 Žalys, V. Lietuvos diplomatijos istorija (1925-1940), t. II, antroji dalis. Vilnius, 2012, p. 245-284.

27 Jakubavičienè, I. Dar kartą apie Ernesto Neumanno ir Teodoro Sasso procesą. Darbai ir dienos, t. LVII, 2012, p. 31-63; Bartininkas, S.; Safronovas, V. Klaipèdos krašto gyventojų pronacistinių orientacijų XX a. 4-ajame dešimtmetyje vertinimo problema. Nauji požiūriai i Klaipèdos miesto ir krašto praeitị (Acta Historica Universitatis Klaipedensi, t. XVII). Sud. S. Pocyte, V. Safronovas. Klaipèda, 2008, p. 101-120. 
ir kareivinès buvo ne tokios, kokias mes turëjome ${ }^{\text {“28 }}$.

Iš Biržų ị kariuomenę paimtas Kazys Leknickas paskyrimą i Klaipedą prième kaip „tremtị“. Atsiminimuose jis teigè: „Paskyrimu buvau nepatenkintas dèl dviejų priežasčių: viena, kad paskyrè ne ị kavaleriją, o antra, kam siunčia taip toli - net ị Klaipèdą. Paskyrimas ị Klaipèdą man buvo tas pats, kaip caro laikais $\mathfrak{i}$ Vladivostoką, taip tada man atrodè toli. “29

Atvykèliais nesidžiaugè ir vietos gyventojai, keliantys šūkị „Klaipėda klaipediečiams!“, o atvykusieji iš Didžiosios Lietuvos, nežinantys vietos tradicijų ir istorijos, stebejjosi miesto švara, pieno išvežiojimu ${ }^{30}$, tuo, kad visas miestas mūrinis ir nèra medinių pastatų, važinèjančiu tramvajumi, oria Klaipèdos vežikų išvaizda ir vežimais ${ }^{31}$.

Apie padètị galima spręsti ir iš to, kad 1938 m., t. y. praejjus penkiolikai metų nuo Klaipedos krašto prijungimo ir ruošiantis minèti Lietuvos nepriklausomybès 20-ąsias metines, Klaipėdos igulos viršininkas konstatavo: „Klaipėdos ir Macikų igulų kariuomenès dalys stovi nepalankiose su vietos visuomene sugyvenimo sąlygose. Dalis visuomenès yra suvokietejjusi, su neapykanta žiūrinti ̣̇ karius, kas sudaro neleidžiančias su jais kariams bendrauti aplinkybes. Ir toji visuomenès dalis gyvena visai nuo karių atsiskyrusi, su jais kultūriškai nieko bendra neturèdama. <...> Šalia vokiškosios dalies esančioji lietuvių visuomenè, su kuria kariams priderètų kultūriškai bendrauti, materialiai yra silpna. Gyvena mažu kultūrinių pramogų skaičiumi. "Konstatuota, kad igulos neturi tinkamų patalpų renginiams, o mieste imamas didelis jų nuomos mokestis ${ }^{32}$.

1936 m. Šilutejje buvo įsteigtas Šaulių choras, tačiau po trejų veiklos metų, 1939 m. kovą, Klaipėdos krašto vyr. dirigentas Alfonsas Mikulskis apgailestavo, „kad iki šiol šilutiškiai neparodè reikiamo supratimo dainos

\footnotetext{
28 Černius, [J.]. Dvylika metų Klaipėdoje. Karys, 1977, sausis, Nr. 1 (1528), p. 1-2.

29 Leknickas, K. Prisiminimai iš Nepriklausomos Lietuvos kariuomenès laikų. Karys, 1963, vasaris, Nr. 2 (1389), p. 52.

30 Vareikis, V. Nuo romantinès praeities ị modernią ateitį. Klaipedda. Istorija populiariai. Klaipeda, 2002, p. 25-27.

31 Strakauskaitè, N. Atstumų būta didelių. Klaipèda. Istorija populiariai. Klaipèda, 2002, p. 116-119.

32 Ažubalis, A. ir kt. Karo pedagogika Lietuvoje (1918-1940 m.). Vilnius, 2007, p. $362-363$.
} 


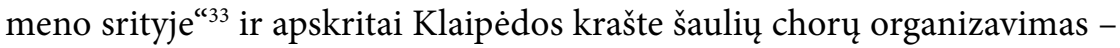
sunkus darbas ${ }^{34}$. Petronèle Žostautaitẻ konstatavo, kad 1923-1939 m. ì Klaipėdos kraštą atvyko daugiau kaip 30000 žmonių iš Didžiosios Lietuvos, tačiau po $1925 \mathrm{~m}$. gyventojų surašymo daugiau nebuvo galimybių tiksliai nustatyti didlietuvių Klaipėdos krašte skaičiaus ${ }^{35}$. 1939 m. rugsèjo 12 d. vyriausybę informavo Lietuvos generalinis konsulas Klaipėdoje, kad tuo metu Klaipèdos krašte pas ūkininkus ir pramonejje dirbo apie 8000 darbininkų iš Lietuvos ${ }^{36}$. Martynas Jankus ir Endrius Borchertas Lietuvos valdžiai siūlè įvairius krašto „kolonizavimo“ didlietuviais planus, teikiant persikèlèliams lengvatas, perkelti ị kraštą kuo daugiau lietuviškų ìstaigų, vykdyti energingą ūkininkų iš Lietuvos „kolonizaciją“, steigti naujas darbo vietas pramonèje ir panašiai. 1936 m. Žemès bankas buvo ịkūręs slaptą fondą, jo lěšomis per keliolika metų trijose zonose krašte turèjo būti apgyvendinta 1250 lietuvių šeimų (iš jų 800 - aplink Klaipedą), bet šie sumanymai nebuvo igyvendinti ${ }^{37}$. Tačiau šaulių būriai buvo dislokuoti palei geležinkelio liniją Bajorai-Klaipèda-Pagègiai-Tauragè ir greta jos ejjusị kelią $^{38}$. I Lietuvos Respublikos įstaigas Klaipèdoje iš Didžiosios Lietuvos buvo siunčiami valdininkai, „ištremti“ dèl tarnybinių nesusipratimų, - jie toli gražu nebuvo geriausi Lietuvos valdžios atstovai ${ }^{39}$. Lietuvos valdžia integruoti Klaipėdos kraštą tikèjosi „kolonizavimo“ būdu, tačiau ši strategija nepasiteisino. I Klaipèdą daugiausia vyko ne patriotiški lietuvių tautinès kultūros skleidejjai, o ịvairūs oportunistai ir komunistuojantys asmenys. Kad yra tokia situacija, netiesiogiai pripažino ir užsienio reikalų minis-

\footnotetext{
33 Pertvarkomas Šilutès šaulių choras. Vakarai, 1939, kovo 17, Nr. 64 (974), p. 4.

34 Klaipedos šaulių vyrų chorui 4 metai. Trimitas, 1939, kovo 16, Nr. 11 (952), p. 262.

35 Žostautaitè, P. Klaipėdos kraštas 1923-1939. Vilnius, 1992, p. 59.

36 Lietuvos generalinis konsulatas, 1939 m. rugsejo 12 d. LCVA, f. 383, ap. 2, b. 20, 1. 33.

37 Žukas, J. Klaipédos krašto ekonomine raida XIX a. antrojoje puseje - XX a. pirmojoje pusejje (1871-1939 m.) [daktaro disertacija]. Klaipėda, 2010, p. 99-100.

38 Jokubauskas, V. Lietuvos šaulių sąungos veikla Klaipėdos krašte 4-ajame XX a. dešimtmetyje: struktūra, uždaviniai ir realybè. Lietuvos šauliu sajunga: praeitis, dabartis, ateitis. Leidinys, skirtas Lietuvos šaulių sajungos gyvavimo 90-mečiui. Sud. R. Varsackytè. Kaunas, 2009, p. 107.

39 Vareikis, V. Nuo romantinès praeities ị modernią ateitį. Klaipéda. Istorija populiariai. Klaipèda, 2002, p. 25-26.
} 
tras Stasys Lozoraitis ${ }^{40}$. Martyno Anyso teigimu, ł̇ Klaipedą vyko „daug oportunistų bei antivalstybinių ar komunistuojančių opozicininkų, kurie i̇vairiais sumetimais greitai persimeta ị kitą pusę“, o, anot S. Lozoraičio, pagrindinis Lietuvos politikos Klaipėdos krašte veikimo principas buvo „infiltracija“, t. y. siekis, kad kuo daugiau lietuvių iš Didžiosios Lietuvos persikeltų ị Klaipèdą, nes „kiekvienas ị Klaipèdą atvažiuojąs lietuvis išpildo tam tikrą misiją “41. Kaip pažymèjo Silva Pocytè, tyrinèjusi mažlietuvių identitetą ir jo raišką Vokietijos imperijoje, šios ministro abejonès buvo pagrịstos, nes mažlietuviai vengè broliautis su didlietuviais ne tik dèl to, kad pastarieji buvo katalikai, bet ir dèl, jų akimis, Rusijos imperijos atsilikimo, grèsmès „pavirsti rusais arba lenkais“42. Po penkiolikos metų, kai Klaipėdos kraštas buvo prijungtas, Lietuviškųjų organizacijų komiteto Klaipèdos krašte memorandume 1938 m. spalị konstatuota, kad Lietuvai ir apskritai lietuviškumui kenkia vietos gyventojų ignoravimas ir gaivališkas, neribojamas žmonių iš Didžiosios Lietuvos antplūdis ị Klaipėdos kraštą, nes „kolonizavimo“ priemonėmis ir vietinių gyventojų stelbimu kraštas nepririšamas prie Valstybès kūno, antraip - tokios ir panašios priemonès sudaro tiktai krašto praradimo užuomazgą"43.

Buvęs Klaipėdos karo komendantas plk. Jonas Andrašūnas prisiminė: „Klaipėdos krašte hitlerininkai jautèsi labai drąsiai ir kèlè galvas. Būdavo mažų nesutarimų su lietuviais ir žydais. Bet vietinè policija ginčus greitai sutvarkydavo. Atėjo Visų šventųjų diena. Hitlerininkai ruošèsi dideliam paradui. Iš Kauno atvažiavo [Kariuomenès štabo II (Žvalgybos ir kontržvalgybos) skyriaus viršininko pavaduotojas] pulkininkas [Petras] Kirlys stebèti jų pasirodymo. Paradas prasidejo vakare, sutemus. Uniformuoti hitlerininkai su svastikomis, vèliavomis, fakelais žygiavo Liepojos gatve giedojo hitlerines dainas. Mes, užgesinę šviesą, pro užuolaidos plyšį žiūrèjome. Prie komendantūros sustojo, o kai kurie, iškèlę kumščius, grasino.

40 Ivanovas, B. Tautiškumo beieškant Antano Smetonos Lietuvoje: tautinių j̇vaizdžiu klausimais. Vilnius, 2005, p. 222.

41 Anysas, J. Kova dèl Klaipédos: atsiminimai 1927-1939. Chicago, 1978, p. 230-231.

42 Pocytè, S. Mažlietuviai Vokietijos imperijoje 1871-1914. Vilnius, 2002, p. 105.

43 Pocytè, S. Klaipediškių / lietuvininkų politinès ir tautinès nuostatos $1939 \mathrm{~m}$. kovo išvakarèse. Klaipédos krašto aneksija 1939 m.: politiniai, ideologiniai, socialiniai ir kariniai aspektai (Acta Historica Universitatis Klaipedensis, t. XXI). Sud. S. Pocytè. Klaipèda, 2010, p. 189. 
Atrodo, ruošèsi sakyti kalbą. Visur buvo policija. Jų vadas davė komandą ir nužygiavo tolyn - kareivinių link. Kaip man [V. Andrašūnui - V. J.] vèliau papasakojo, jie norèjo įeiti ị lietuvių kareivines, bet vietinè policija jų neleido. Taip atejo 1939 metų kovo mèn. ${ }^{* 44}$

Dvylikametis banko tarnautojo sūnus Romualdas Bèkšta prisiminè, kad artëjant anšliusui Klaipėdoje šeimininkavo uniformuoti SA vyrukai, „lyg Klaipėda nebūtų buvusi 1923 metų sausio mènesị prijungta prie Lietuvos, tegu ir autonomijos pagrindu. Čia [Seimelio rinkimų apylinkejje 1938 m. gruodžio 11 d. - V. J.] geriau lietuviškai nekalbèti, nes gali gauti per marmūzę “45.

1938 m. lapkričio $25 \mathrm{~d}$. XX rinktinès vado isakyme pabrèžiama, kad krašte atšaukus karo padèti situacija pasikeite, ir įsakè šauliams savarankiškai jokių veiksmų be vado nurodymo nesiimti. Taip pat pažymejjo, kad „ne vienam jautresnès sielos lietuviui-šauliui skaudu, kai šio krašto [Klaipédos - V. J.] broliai lietuvininkai pamynè po kojų savo tèvų bei protèvių lietuvišką kilmę ir, atsisakę nuo kūrybinio darbo nepriklausomos Lietuvos naudai, nuejo vèl vergauti“"46. Lietuvos karinè žvalgyba ịžvelgè skirtumą tarp Klaipèdos krašto ir likusios Lietuvos, lygindama ir konstatuodama, kad šalyje nemažai lietuviškų organizacijų narių yra valdininkai, tačiau Klaipeddos krašte dauguma jų, atvykusių iš Didžiosios Lietuvos, buvo ne lietuviai, o vokiečiai, nes esminis paskyrimo kriterijus buvo vokiečių kalbos mokejjimas. Todèl dalis net centrinès valdžios pasiųstų ir Klaipėdos krašte dirbusių valdininkų ì Lietuvos valstybę žiūrèjo rezervuotai. Štai gubernatūros Pagègių pasų ístaigoje buvo bendraujama vokiečių kalba, o tarnautojai ne kartą sakè „esą vokiečiai, o lietuviai yra okupantai“" ${ }^{47}$. Klaipẻdos krašto gyventojų nuotaikas Lietuvos atžvilgiu atskleide ir Klaipėdos krašto komendantas savo raporte 4-ojo AP vadui, naujokus iš šio krašto apibūdindamas iškalbingomis frazèmis: „vokiško nusistatymo“, „lietuvių

\footnotetext{
44 Andrašūnas, J. Klaipèda - 1938-1939-ieji. Kardas, 1991, Nr. 3, p. 27.

45 Bèkšta, R. Gyvenimas Malku gatveje. Atsiminimai apie tarpukario Klaipédą. Vilnius, 2015, p. 167-168.

${ }^{46}$ XX Klaipedos rinktinès vado 1938 m. lapkričio 25 d. ịsakymas. LCVA, f. 561, ap. 2, b. 1301, 1. 283.

47 Klaipedos lietuvių visuomeninis ir tautiškas gyvenimas [1933 m.]. LCVA, f. 929, ap. 2, b. 112, 1. 265.
} 
neapkenčia“, „SOVOG narys“, „vietinis lietuvis, tačiau vokiško nusistatymo ir neapkenčia lietuvių“ arba „vokiečių tautybès, yra aiškios vokiškos orientacijos, nors ir priklauso prie Kebeikių šaulių būrio“" ${ }^{48}$.

1939 m. buvo išsiaiškinta, kad dalis centrinès valdžios ịstaigų, muitinès, pašto, telegrafo, geležinkelio valdininkų Pagėgių apskrityje ir net Tautinio lietuvių banko Pagègių skyriaus direktorius priklausė SA ${ }^{49}$. Taigi Klaipèdos krašte tarp lietuvininkų ir Lietuvos Respublikos centrinès valdžios bei persikèlèlių iš Didžiosios Lietuvos tvyrojo abipusis nepasitikejjimas, plito separatistinès idèjos, o tai nebuvo palanki terpè karinei gynybai organizuoti ir karo atveju ginti kraštą.

\section{LIETUVOS POLITIKOS NESĖKMĖS ISITVIRTINANT KLAIPĖDOS KRAŠTE}

1935 m. pasienio zona, kur buvo stengiamasi sustiprinti šaulių pajègas, laikyta $20 \mathrm{~km}$ nuo sienos ir administracinès linijos, o Klaipėdos krašto pasienio zonos $20 \mathrm{~km}$ buvo skaičiuojami nuo buvusios Didžiosios Lietuvos ir Klaipèdos krašto sienos ${ }^{50}$. $1936 \mathrm{~m}$. gegužès $25 \mathrm{~d}$. Kariuomenès štabe svarstant jūros pakrančių gynimo klausimą, štabo I skyriaus Mokymo dalies vedejjas gen. št. plk. ltn. Leonas Rupšys ir IV skyriaus viršininkas gen. št. plk. ltn. Bronius Gertus teigè, kad „Klaipèdos uostas, kaip bazé, tinka tik lenkų, rusų ir latvių atžvilgiu, gi vokiečiu atžvilgiu - netinka, nes uostas karo veiksmų pradžioje gali būti užimtas iš sausumos. Tuo būdu turimas laivynas bus priverstas ieškoti prieglobsčio neutralių valstybių ar galimų sąjungininkų uostuose. <...> dabartiniu metu [1936 m. - V. J.] aktualus priešas yra vokiečiai, ir laivynas, kaip toks, vokiečių atžvilgiu save mažai tepateisintų “"

\footnotetext{
48 Pacevičius, P. Lietuvos kariuomenès dezertyrai 1918-1940 m. [magistro baigiamasis darbas]. Kaunas, 2012, p. 55.

49 Pranešimas Nr. 37, 1939 m. vasario 25 d. LCVA, f. 929, ap. 2, b. 1052, 1. 146.

50 LŠS vado 1935 m. rugsèjo 25 d. įsakymas. LCVA, f. 561, ap. 2, b. 859, 1. 71.

511936 m. gegužès 25 d. pasitarimo Kariuomenès štabe protokolas. LCVA, f. 929, ap. 9,
} 
1937 m. gegužès mèn. raporte krašto apsaugos ministrui plk. Stasiui Dirmantui kariuomenès vadas gen. št. plk. Stasys Raštikis rašè: „Labai sunku prileisti, kad sustiprejjusi Vokietija paliktų jos niekinamai Lietuvai Klaipėdos kraštą. Vokietijos pavojui eliminuoti priemonių nèra. Yra priemonių tik ją nutęsti į tolimesnę ateitị, o tos priemonès yra kiek galima stiprinti savo karinị pajègumą ir suartèti su valstybèmis ir jų blokais, kurie suinteresuoti Vokietijos pažabojimu. “52

1937 m. karo atveju buvo planuojama „panaudoti visus nemobilizuojamus, patikimus, valstybiško nusistatymo, tinkančius apsaugai bei kovos uždaviniams šaulius. Tomis sąlygomis visiems numatytiems uždaviniams pakanka nemobilizuojamo amžiaus šaulių skaičiaus, išskyrus Klaipėdos krašto, t. y. XX šaulių rinktinès, kurioje vos tik pakanka išstatyti prie svarbesnių objektų sargybas bei patrulius, neturint net antros pamainos, ir tai ne visoje rinktinèje. Pavyzdžiui, Pagègių apskrities šaulių kuopos visi nepaliesti mobilizacijos šauliai naudojami kaipo svarbesniam reikalui, operacinio uždavinio vykdymui, 7 / I b-no vado valdžioje, kurio parẻdymais saugo ir svarbesnius objektus, kaip, pvz., Tilžès tiltas per Nemuną"53.

Svarstant pasienio su Vokietija Klaipedos krašte apsaugos problemą buvo siūloma šią VRM funkciją Klaipèdos krašte perduoti kariuomenei ir iš privalomosios karo tarnybos karių, kurie dèl komplikuotos tarnybos Klaipèdos krašte turejjo būti „ypač pavyzdingi“, suformuoti 1-2 batalionus, o apie šaulių naudojimą net neužsimenama ${ }^{54} .1936 \mathrm{~m}$. patvirtinus naują mobilizacijos tvarkaraštị Nr. 4, pasienyje su Lenkija ir Vokietija priedangai iš pasieniečių ir šaulių turèjo būti suformuoti PAB, tačiau I-III PAB buvo numatyta formuoti ir išdèstyti ne pasienyje su Vokietija, o Žemaitijoje, palei Klaipèdos kraštą ${ }^{55}$. Batalionai turèjo būti formuojami vien iš Kretingos,

b. $165,1.32-32$, apv. 1 .

52 Žalys, V. Lietuvos diplomatinès tarnybos ir kariuomenės vadovybès sąveika ịtvirtinant Lietuvos valstybingumą 1923-1938 metais. Lietuvos nepriklausomybei - 80. Straipsniu rinkinys. Vilnius, 1999, p. 71.

53 III PD šaulių panaudojimo planas. Paaiškinamasis lapelis. 1937 m. LCVA, f. 929, ap. 3, b. 957, ap. 1. 2.

54 Pastabos pasienio apsaugos organizacijos reikalu, $1935 \mathrm{~m}$. liepos 31 d. LCVA, f. 929, ap. 5 , b. $449,1.84-85$.

55 Vaičenonis, J. Lietuvos šaulių sąjunga valstybès gynyboje 1935-1940 m. Lietuvos šauliu sajungos istorijos fragmentai. Konferencijos pranešimų medžiaga. Red. J. Vaičenonis; 
Tauragès ir Raseinių apskričių šaulių ${ }^{56}$. Ir tik esant palankioms sąlygoms, gavus atskirą kariuomenès vado ịsakymą, daliniai Klaipėdos krašte turèjo užimti ir ginti Nemuno upès pozicijas ${ }^{57}$. Panašiai $1940 \mathrm{~m}$. atgautame Vilniaus krašte dèl vietos gyventojų nepatikimumo buvo atsisakyta formuoti $\mathrm{PAB}^{58}$. Šis taktinis sprendimas rodo kadrų, reikalingų PAB Klaipèdos krašte sudaryti, stygių, vietos gyventojų gana nepalankų požiūrị i Lietuvos kariuomenę ir tai, kad karo su Vokietija atveju Lietuvos kariuomenès galimybès ginti natūralias Nemuno upès ribas buvo komplikuotos.

1935 m. Lietuvos kariuomenès mobilizacijos direktyvoje nurodyta, kad pasieniui saugoti galèjo būti pasitelkti tik nemobilizuojami „lietuviško nusistatymo ir pilnai patikimi“ šauliai ${ }^{59}$. Tai kodèl tokių batalionų nebuvo planuojama formuoti Klaipèdos krašte, pasienyje su Vokietija, iš vietos šaulių?

Nepatikimumą ir informacijos nutekinimą liudija šis atvejis. Kai 1938 m. balandžio 27 d. Kariuomenès teismas XX Klaipėdos rinktinès šaulị Ernestą Žemaitaitị nuteisẻ 15 metų sunkiųjų darbų kalẻjimo už tai, kad 1937 m. lapkričio 25 d. jis nuvyko ị Tilžę ir Vokietijos slaptosios policijos valdininkui suteikè žinių apie Lietuvos kariuomenès dalinių dislokaciją ir priklausomybę, Pagégiuose ir Macikuose stovejusių kuopų pavaldumą. Taip pat papasakojo apie LŠS veiklą ir santykius su kitomis Klaipèdos krašto organizacijomis, pateikè pasienio policijos išdèstymo duomenis ${ }^{60}$. E. Žemaitaitis (g. 1910 m.) 1931-1933 m. tarnavo Lietuvos kariuomenès 2-ajame PP, nuo $1935 \mathrm{~m}$. rugpjūčio $14 \mathrm{~d}$. buvo šaulys kandidatas, ị LŠS istojo $1936 \mathrm{~m}$. balandžio $22 \mathrm{~d} .{ }^{61}$

1938 m. prasidejusi Lietuvos ir Lenkijos politinè krizè dèl Lenkijos Lietuvai pateikto ultimatumo galejo baigtis ir Klaipèdos užèmimu. Vokietijos karinès jūrų pajègos buvo sutelktos prie Bornholmo salos, kad galètų Klai-

\footnotetext{
S. Dovydaitis. Kaunas, 2002, p. 113-115.

56 Pasienio apsaugos dalių sąrašas. Mob. tv. Nr. 4. LCVA, f. 929, ap. 3, b. 848, 1. 117.

57 Kariuomenès štabo 1937 m. gegužès 25 d. ịsakymas III PD vadui. LCVA, f. 929, ap. 3, b. $988,1.4$.

58 Kariuomenès mobilizacijos reikalu. 1940 m. LCVA, f. 929, ap. 5, b. 591, 1. 30.

59 Kariuomenès mobilizacijai parengti ir vykdyti direktyva. Mob. tv. Nr. 11 ir Nr. 12, 1935 m. LCVA, f. 929, ap. 3, b. 848, 1. 22.

601938 m. bylos Nr. 181 nuorašas. LCVA, f. 561, ap. 2, b. 1301, 1. 78-78 apv. 1.

61 Liudijimas Nr. 91 260. LCVA, f. 561, ap. 2, b. 1301, 1. 73.
} 
pėdą pasiekti per keletą valandų. Lenkijos ir Lietuvos karo atveju Vokietija buvo pasiruošusi įsikišti. Adolfas Hitleris davė įsakymą generaliniam štabui parengti Klaipẻdos krašto ir aplinkinių Lietuvos rajonų užèmimo planą. Kovo 18 d. Vokietijos daliniai Rytprūsiuose įžengè ì puolimui parengtas zonas, o desanto korpusas kreiseriais Nürnberg, Köln ir Leipzig pajudejo Klaipèdos link ${ }^{62}$. Pagal planą Flottenparade (liet. Laivyno paradas) puolime turejo dalyvauti apie 15 ịvairių karo laivų. Nors Vokietija 1938 m. kovo mèn. karo su Lietuva nenorejo ir neprovokavo, bet, Lenkijai užpuolus Lietuvą, ir vokiečiai būtų ịsiveržę ì jos teritoriją ${ }^{63} .1938 \mathrm{~m}$. Vokietijos kariuomenè buvo parengusi manevrų planą, jame modeliuotas ir karo su Lietuva scenarijus, vermachto veiksmai prieš Lietuvos kariuomenę ${ }^{64}$. Vokietijos kariuomenè planavo užimti Klaipedos kraštą ir Žemaitiją iki Šiaulių, t. y. apie $15000 \mathrm{~km}^{2}$ teritoriją ${ }^{65}$. Žinoma, galima svarstyti, ar reali buvo Lenkijos agresijos galimybė $1938 \mathrm{~m}$. kovą, juk tuo metu Lietuvos kariuomenès štabas konstatavo, kad 1938 m. kovo 17-19 d. Lenkijos kariuomenè Vilnius krašte judejo tik parodomaisiais tikslais, nes „su tiek jègų lenkai negalejo tikètis okupuoti kraštą [Lietuvą - V. J.] “66. Iš Lenkijos pajègu judejimo Lietuvos kariuomenejje buvo padaryta išvada, kad galima tikètis puolimo trimis kryptimis: 1) Kalvarija-Marijampolè; 2) MerkinèAlytus-Prienai; 3) Vilnius-Kaišiadorys-Kaunas. Lenkija kitapus sienos turèjo sutelkusi apie 3 PD, 5 KP, 1 SAP ir 30 tankų ${ }^{67}$. Lietuvos vyriausybei prièmus Lenkijos ultimatumą ir vokiečiai nutraukè parengiamuosius darbus, o $1938 \mathrm{~m}$. kovo $21 \mathrm{~d}$. Lietuvos kariuomenès štabo II skyrius konstatavo, kad Lenkijos kariuomenè nuo administracinès linijos atsitraukè ir

\footnotetext{
62 Vareikis, V. Klaipèda XX amžiuje. Klaipèda, 1993, p. 42.

63 Liekis, Š. „Laivyno paradas“ ir neįvykusi Klaipėdos okupacija 1938 m. Nežinomi Lietuvos ir Vokietijos santykių puslapiai. Genocidas ir rezistencija, 2004, Nr. 2 (16), p. 163-168. 64 Kriegsspiel Ostpreußen 1938. Schlußbesprechung. Центральный архив Министерства обороны (ЦАМО), Ф. 500, оп. 12451, д. 20. [žr. 201507 02] http://wwii. germandocsinrussia.org/ru/nodes/843\#page/1/mode/inspect/zoom/5.

65 Rauch, G. The Baltic States: The years of independence Estonia, Latvia, Lithuania 19171940. London, 2006, p. 196.

66 Daviniai apie 1938 m. kovo 17-19 d. lenkų rengimąsi pulti Lietuvą. LCVA, f. 929, ap. 3, b. $1022,1.5$.

67 Ten pat, 1. 4.
} 
grižzo ị savo igulas ${ }^{68}$.

Lygiai po metų, kai dèl Lenkijos ultimatumo kilo krizè, 1939 m. kovo 20 d., Vokietija pateikè savo ultimatumą, reikalaudama perduoti Klaipėdos kraštą ${ }^{69}$. Vokietijos ultimatumas Lietuvos vyriausybei nebuvo nei naujiena, nei netikètumas, nes dar 1938 m. pabaigoje diplomatai pasiuntè informaciją apie galimą Klaipèdos anšliusą. 1938 m. pabaigoje-1939 m. pradžioje Lietuvos valdžia dèl neaiškių santykių su Vokietija išgyveno tikrą stresą. Klaipėdos krašto konvencijos signatarių pasyvumas vertė Lietuvą ieškoti dialogo su Vokietija, tačiau Juozo Urbšio iniciatyva ir pastangos buvo bevaisès. Vokietija nereagavo $\mathfrak{i}$ Lietuvos paklausimus ir vengè susitikti aukščiausiu lygiu ${ }^{70}$. Lietuva siekè dialogo aukščiausiu lygiu ir norejo užsitikrinti sienos su Vokietija stabilumą darydama nuolaidas Klaipėdos krašte, leisdama autonomijos statusą taikyti taip, kaip interpretavo Vokietija ${ }^{71}$. 1938 m. lapkričio 7 d. pasiuntinys Rygoje užsienio reikalų ministrui pranešè, kad turi žinių, jog Vokietija greitai rengiasi išspręsti Klaipėdos krašto klausimą, prijungdama ji prie Vokietijos ${ }^{72}$. Lietuvos generalinis konsulas Königsberge (Karaliaučiuje) informavo, kad vietiniai nacių vadovai mano, jog Klaipeddos kraštas yra vokiškas ir palikti ji svetimos valstybės, t. y. Lietuvos, sudètyje prieš gyventojų valią negalima. Tad lieka tik nuspręsti, koks klaipèdiečių „valios“ igyvendinimo, t. y. Klaipėdos krašto prijungimo prie Vokietijos, būdas būtų tinkamiausias ${ }^{73} .1938 \mathrm{~m}$. gruodžio $12 \mathrm{~d}$. Lietuvos atstovas Taline rašè turịs žinių, kad „Klaipėdos Anschluss’as esąs neišvengiamas tuoj po rinkimų ar netolimoj ateityje“. Diplomatas konstatavo, kad Berlynas nenori, bet yra priverstas rūpintis vietiniais Klaipèdos krašto tautiečiais - vokiečiais. Ir nurodè, kad turima informacija, gauta iš Londono, rodo, jog anglai nieko negalès daryti, jei Klaipédos gyventojai

\footnotetext{
68 Kariuomenès štabo II skyriaus biuletenis Nr. 5, 1938 m. kovo 21 d. LCVA, f. 929, ap. 3, b. $1022,1.15$.

69 Urbšys, J. Lietuva lemtingaisiais 1939-1940 metais. Vilnius, 1988, p. 10-11.

70 Kasparavičius, A. 1939 metų tarptautinè krizė Europoje ir Baltijos valstybių politikos alternatyvos. Lietuva Antrajame pasauliniame kare. Sud. A. Anušauskas; Č. Laurinavičius. Vilnius, 2007, p. 21-22.

71 Urbšys, J. Lietuva lemtingaisiais 1939-1940 metais. Vilnius, 1988, p. 10.

72 Lietuvos pasiuntinybė Rygoje, 1938 m. lapkričio 7 d. LCVA, f. 383, ap. 7, b. 2048, 1. 195.

73 Lietuvos generalinis konsulas Karaliaučiuje L. Dymša, 1938 m. gruodžio 30 d. LCVA, f. 383 , ap. 7, b. 2048, 1. 14 .
} 
pareikš norą susijungti su Vokietija ${ }^{74}$.

1939 m. kovo 16 d. diplomatą Kazị Balutị Didžiosios Britanijos URM departamento vadovas Laurencas Collieras informavo, kad Didžioji Britanija suteikti paramos negalès ir Lietuva pati turi nuspręsti, kaip elgtis. Panašų atsakymą Lietuvos diplomatas gavo ir Paryžiuje. Lietuvos diplomatai jau anksčiau buvo susitaikę su mintimi, kad šalis neteks Klaipèdos krašto. Nerimą dèl Klaipėdos dar labiau sustiprino 1939 m. kovo 10-17 d. pasiuntinio Berlyne Kazio Škirpos atsiųsti pranešimai, kuriuose buvo net iqvardyta konkreti data - kovo $14 \mathrm{~d}$. Nors tada Vokietijos pajegos pajudèjo ị Prahą, tačiau ịtampa ir grèsmès nuojauta neatslūgo. Todèl diplomatai tik svarstè, kokia forma bus perduotas Klaipėdos kraštas ir ar Lietuva nesulauks Čekoslovakijos likimo, t. y. visiškos okupacijos. 1939 m. vasario pradžioje diplomatas Petras Klimas Klaipèdos problemą apibūdino trumpai: „Klaipėdos išsaugojimas tik tada turi prasmès, kada jis nestato pavojun visos Lietuvos likimo.“75 1939 m. kovo 13 d. Lietuvos ministras pirmininkas Vladas Mironas užsiminė Didžiosios Britanijos pasiuntiniui, kad Vokietijos anšliusui tereikia Seimelio pritarimo. Kartu ministras pirmininkas pripažino, kad šešiolikos metų kova dèl Klaipėdos pralaimèta. Itampa Klaipėdos krašte pasiekẻ aukščiausią tašką, kai vokiečiai įžygiavo ị Čekoslovakiją ir užèmè Prahą ${ }^{76}$.

Vokietijos Lietuvai primestą sutartí, datuotą 1939 m. kovo 22 d., Berlyne pasirašè Lietuvos atstovai J. Urbšys ir K. Škirpa ir Vokietijos atstovas Joachimas von Ribbentropas. Kitą dieną Vokietijos kariuomenė užèmė Klaipėdos kraštą. Joachimas Tauberis rašè: „1939 m. kovo 23 d. pirmą kartą pasirodè scenarijus, kuris turejo nulemti Baltijos valstybių likimą."

Agresyvi Vokietijos politika ir Klaipėdos praradimas Lietuvos karinę vadovybę vertė dar labiau susirūpinti dèl Trečiojo reicho keliamos grès-

\footnotetext{
74 Lietuvos pasiuntinybė Taline, slaptai užsienio reikalų ministrui, $1938 \mathrm{~m}$. gruodžio 12 d. LCVA, f. 383, ap. 7, b. 2048, 1. 72.

75 Kasparavičius, A. 1939 metų tarptautinè krizė Europoje ir Baltijos valstybių politikos alternatyvos. Lietuva Antrajame pasauliniame kare. Sud. A. Anušauskas; Č. Laurinavičius. Vilnius, 2007, p. 22-24.

76 Vareikis, V. Klaipėda XX amžiuje. Klaipedda, 1993, p. 45.

77 Tauber, J. Lietuvos-Vokietijos santykiai: Paskutiniai Lietuvos Respublikos mènesiai: 1939 m. kovas-1940 m. birželis [paskaitų mašinraštis: Klaipedos universiteto Baltijos regiono istorijos ir archeologijos instituto biblioteka]. Klaipèda, 1. 12.
} 
mès. 1939 m. pavasarị ministras pirmininkas brg. gen. Jonas Černius pokalbio su Lenkijos karo atašè plk. Leonu Mitkiewicziumi metu energingai pritarė „prevenciniam karui“ su Vokietija konstatuodamas, kad „lenku koridoriaus" klausimas Lietuvos saugumui itin svarbus, nes, Vokietijai geografiškai susijungus su Rytų Prūsija, Lietuvos ir kitų Baltijos šalių padètis itin pablogètų ir jos negalètų priešintis Vokietijos hegemonijai ${ }^{78}$. Algimanto Kasparavičiaus teigimu, dokumentai leidžia kelti versiją, kad Prancūzijos ir Didžiosios Britanijos laikysena padejo išspręsti Lietuvos „dilemą: aktyviai priešintis Trečiajam Reichui ar ne“. Kauno ryžtą tam tikromis aplinkybėmis karine jèga ar politiškai priešintis Vokietijai konstatuoja to meto SSRS diplomatai, rezidavę Lietuvoje ${ }^{79}$.

1939 m. kovo 19 d. dienraštyje Vakarai buvo pažymèta, kad Klaipedos siuvejai intensyviai siuva naujas Klaipėdos krašto ir Vokietijos vèliavas su svastikomis, vienas su savo mokiniu per naktị pasiuvo net 250 tokių vèliavų. Laikraštyje konstatuota: „Šiandien gatvėse jau daug daugiau vèliavų su svastikomis. Dabar miestas marguoja žaliai-baltai-raudonomis ir vokiškomis vèliavomis. “" Kitą dieną, t. y. kovo 20-ąją, Lietuvos vyriausybės posèdyje buvo nutarta Klaipedos krašto seimelio priimtą nutarimą arba Ernsto Neumanno atliktus veiksmus, prieštaraujančius Klaipėdos krašto statutui, toleruoti, kol nekils tiesioginis pavojus valstybei, o sukilusius krašto vokiečius nuraminti pasitelkus kariuomenę. Jei tai sukeltų Vokietijos agresiją, nuspręsta Lietuvos kariuomenę be pasipriešinimo atitraukti iš krašto ir karo veiksmus pradèti Didžiojoje Lietuvoje, taip pat apie gresiantị pavojų informuoti Prancūziją ir Didžiąją Britaniją ir prašyti jų patarimo. Posėdyje buvo nutarta, pastebejjus destruktyvią vokiečių ir lenkų mažumų veiklą, griežčiau prižiūrèti administracinị aparatą, ịvairiose organizacijose griežtinti discipliną, intensyvinti propagandą spaudoje ir per radiją ${ }^{81}$.

Klaipėdos krašte Lietuvos kariuomenè akylai stebejo padètį, tačiau ìvykiai rutuliojosi pačia nepalankiausia linkme, o kariuomenè pakeisti

\footnotetext{
78 Lietuvos ir Lenkijos diplomatiniai santykiai 1938-1940 metais. Sud. A. Kasparavičius; P. Libera. Vilnius, 2013, p. 27, 342-344.

79 Kasparavičius, A. Lietuva 1938-1939 m. neutraliteto iliuzijos. Vilnius, 2010, p. 99, 135.

80 Klaipėdos nuotaikos. Vakarai, 1939, kovo 18, Nr. 65 (975), p. 10.

81 Ministrų tarybos posèdžio protokolas, 1939 m. kovo 20 d. LCVA, f. 923, ap. 1, b. 1080, 1. $46-46$ apv. 1.
} 
jų tèkmę vargu ar galejo, nebent pradėdama karą su Vokietija. 1938 m. kilus įtampai Klaipėdoje ir padaugẻjus vokiečių provokacijų, čia stovèjusiuose daliniuose buvo paskelbta ypatingoji padètis, daliniams įsakyta ypatingą demesi skirti sienos su Vokietija apsaugai ir rengtis vykdyti Klaipédos krašto gynybos planą, tikintis didelio Vokietijos politinio ir karinio spaudimo, nors realios Klaipėdos igulos galimybès, kilus neramumams ar ginkluotam sukilimui, buvo ribotos. $1938 \mathrm{~m}$. birželio $10 \mathrm{~d}$. III PD vadas kariuomenès vadui raportavo:

„Stipresnių vietos neramumų atveju visų esančių Klaipėdoje dalinių pajëgumo nepakaktų patikrinti kareivinių, svarbiausių ịstaigų bei i̇monių apsaugą ir palaikyti tvarką mieste, nekalbant apie mobilizacijos vykdymą bei veiksmus už miesto ribų tikslu ginti miestą. Apie uosto ir krantų gynimą nuo galimų desantų netenka ir kalbèti - priemonių tam visai nėra. <...> Klaipeddoje nesant realios, pakankamai stiprios, nuolat viešai pasirodančios pajègos, vietos lietuviai ir mums prielankioji vokiškoji bei žydiškoji visuomenè nustoja pasitikèjimo dèl ateities. Toji aplinkybė ne vieną verčia dairytis ir ị kitą, jègą demonstruojančią, pusę, tarnauti dviem ponams. " ${ }^{2}$

Brg. gen. Mikas Rèklaitis pasiūlè Klaipèdoje laikyti sustiprintą priedangos batalioną, tankų būrị ir motorizuotąją artileriją, o mobilizacijos centrą perkelti ị Kretingą. Pasirūpinti mokomojo karo laivo Prezidentas Smetona apginklavimu, formuoti pakrančių artilerijos ir hidroplanų dalinius ${ }^{83}$. I generolo pastabas buvo atsižvelgta ir igula sustiprinta. $1938 \mathrm{~m}$. sausio 1 d. visame 6-ajame PP tarnavo 1115 karių $^{84}$, bet vienas pulko batalionas stovejo Plungèje. Klaipėdoje 1938 m. spalio 24 d. buvo 540 6-ojo PP karių, Plungès iguloje - 202 6-ojo PP kariai, iš viso pulką sudare 742 kariai ${ }^{85}$. 1939 m. kovo 1 d. 6-ajame PP iš viso tarnavo 1295 kariai $^{86}$. Kovo 20 d. pulko vadas raportavo, kad kovo $15 \mathrm{~d}$. ̣̇ Klaipèdos igulą atvyko 150 kareivių iš

82 III PD vado 1938 m. birželio 10 d. raportas. LCVA, f. 929, ap. 3, b. 1062, 1. 23.

83 III PD vado 1938 m. birželio 10 d. raportas. LCVA, f. 929, ap. 3, b. 1062, apv. 1. 23.

84 Kariuomenès žmonių ir arklių sudèties žinios. 1938 m. sausio 1 d. LCVA, f. 929, ap. 5, b. $527,1.1$.

${ }^{85}$ 6-ojo PP vado 1938 m. spalio 24 d. raportas. LCVA, f. 519, ap. 1, b. 349, 1. 33.

86 Klaipeddos krašte ir Žemaitijoje dislokuotoje III PD buvo 4708 žmonės (237 karininkai, 4031 šauktinis, 323 „virštarnybiniai“ kariai, 68 civiliai tarnautojai ir 49 auklètiniai), o kartu su 3-iuoju KP ir 3-iąja RAB - 5732 žmonės. Žr.: Žmonių ir arklių sudèties žinios, 1939 m. kovo 30 d. LCVA, f. 929, ap. 5, b. 564, l. 4-4 apv. 1. 
kitų dalinių (iš 1-ojo PP - 68, iš 3-iojo PP - 55, iš 4-ojo PP - 27). Raporte teigiama, kad „visi paskirstyti ił pulko dalinius Klaipèdoje papildant šaulių kuopas ir s. kulk. Kuopą iki pilno etatinio žmonių skaičiaus. Tik RšKp [ryšių kuopai - V. J.] iki etatinio skaičiaus trūksta 32 žmonių. Dabartiniu metu Klaipèdoje kareivinès perpildytos ir daugiau žmonių jokiu būdu nebūtų galimybès sutalpinti“" ${ }^{\text {87}}$. Palyginus su ankstesnių metų statistiniais pulko sudèties duomenimis pastebima, kad jis padidejo keliais šimtais karių $^{88}$, bet politiniame fronte vis labiau buvo atsitraukiama.

1938 m. lapkričio 1 d. Lietuvos vyriausybè, sukeldama daugiatūkstantines džiūgaujančių vietos gyventojų manifestacijas, atšaukė „Valstybès gynimo metą (karo stovio padètị) “89. Padètis 1938 m. pabaigoje Klaipèdos krašte tapo kritiška. Nuo Klaipedos krašto policininkų kepurių buvo nuimti Lietuvos heraldikos ženklai, vokiški pavadinimai sumirgejjo stotyse, pašte ir gatvėse ${ }^{90}$, buvo užpuldinejjami lietuviai, daužomi mokyklų langai, iš privačių mokyklų išmesti Vytis ir Respublikos Prezidento portretai, Ordnungsdiensto nariai užkabinejjo net uniformuotus kariškius ir aktyvius lietuvių veikejjus, tarp jų ir Martyną Jankų ${ }^{91}$.

1938 m. lapkričio 17 d. 7-ojo PP vadas plk. P. Genys divizijos vadui rašè: „Klaipèdos krašto Kulturverband smogiamųjų dalių SA vyrai atvirai ir intensyviai varo karinị mokymą. "Pulkininkas pažymėjo, jog pastaruoju metu jie stengiasi rengti kuo daugiau karinių mokymų Klaipėdos krašte tam, kad rinktų informaciją apie ịvykius ir demonstruotų jègą vietos gyventojams $^{92}$. III PD vadas 7-ojo PP vadui nurodè stebèti įvykius krašte,

\footnotetext{
87 6-ojo PP vado 1939 m. kovo 20 d. raportas III PD vadui. LCVA, 519, ap. 1, b. 383, l. 68. 88 Jokubauskas, V. Lietuvos trispalvè virš kareivinių. Kareivinès, tapusios Klaipėdos universitetu: studija, skirta Klaipédos universiteto Baltijos regiono istorijos ir archeologijos instituto 20-mečiui, Klaipédos universiteto 20-mečiui ir Klaipédos miesto 760-mečiui. Sud. V. Safronovas. Klaipeda, 2012, p. 84.

891938 m. spalio 31 d. Respublikos Prezidento aktas Nr. 1441. Vyriausybès žinios, 1938, Nr. 624, p. 541.

90 Vareikis, V. Politiniai ir kariniai Klaipedos krašto praradimo aspektai 1938-1939 metais. Klaipédos krašto aneksija 1939 m.: politiniai, ideologiniai, socialiniai ir kariniai aspektai (Acta Historica Universitatis Klaipedensis, t. XXI). Sud. S. Pocytè. Klaipèda, 2010, p. $70-71$.

91 Ivykiai Klaipėdos krašte karo stovị nuėmus, nuo 1938 m. lapkričio 1 d. iki 25 d. LCVA, f. 383, ap. 7, b. 2085, 1. 51.

92 Raportas III PD vadui. 1938 m. lapkričio 17 d. LCVA, f. 929, ap. 2, b. 1055, 1. 228.
} 
rinkti ir siųsti informaciją divizijos štabui ${ }^{93}$. Slapta $1939 \mathrm{~m}$. sausio $25 \mathrm{~d}$. Karo taryboje buvo sutarta, kad, „atsižiūrint ị pakitėjusias aplinkybes, reikia eiti prie to, kad klaipédiečiai tarnautų kariuomenejje tik savanoriais. Visus kitus klaipėdiečius reikètų atleisti nuo karo tarnybos ${ }^{\text {“94 }} .1939$ m. kovo 2 d. III PD vadas informavo 6-ojo PP vadą, kad kariuomenès vado įsakymu jauni kareiviai ị Klaipèdą artimiausiu metu nebus skiriami, o igulą reikia „nuolat laikyti galimai pilnesneje sudètyje ${ }^{\text {“95 }}$. Kovo $2 \mathrm{~d}$. kariuomenès vadas ịsakè 1 tankų būrị „apsaugos reikalams“ pasiųsti $\mathfrak{i}$ Klaipėdą ${ }^{96}$. Kovo 3 d. Kariuomenès štabas nurodè vieną 6-ojo PP batalioną skubiai perkelti $\mathfrak{i}$ Kretingą, kur karo atveju turejjo vykti pulko mobilizacija, vieną priedangos sudèties batalioną palikti Klaipèdoje ir atleisti nuo mobilizacijos, o Klaipèdos krašto atsargos karių mobilizacijos atveju nešaukti ${ }^{97}$.

1939 m. kovo 5 d. ị Klaipèdą 6-ojo PP vado žinion buvo pasiųstas lengvųjų tankų būrys ${ }^{98}$. Ltn. Juozo Gaidamavičiaus vadovaujamo būrio motorizuotosios priemonès buvo 5 tankai, sunkvežimis, motociklas, o personalas - 1 karininkas ir 16 kareivių ${ }^{99}$. Atvykęs ị Klaipėdą 2-osios kuopos II būrys, tankai ir motociklas buvo sutalpinti garažuose. Kariai įsikūrè bendroje patalpoje, kuri kartu buvo ir klasè, ir sandèlis, nes sandèliavimui skirtos patalpos buvo labai drégnos ${ }^{100}$. Kovo $17 \mathrm{~d}$. 6-ojo PP vadas gen. št. plk. A. Breimelis gavo ịsakymą evakuoti dalị pulko mobilizacinio turto ił Kretingą, kadangi ten buvo perkeltas pulko mobilizacijos centras. Darbas buvo pradètas $20 \mathrm{~d}$. ir iki $21 \mathrm{~d}$. vyko pagal planą ${ }^{101}$. Be to, buvo nu-

\footnotetext{
93 III PD štabas 7-ojo PP vadui, 1938 m. gruodžio 8 d. LCVA, f. 929, ap. 2, b. 1055, 1. 231. 94 Karo tarybos 1939 m. sausio 25 d. posèdžio protokolas. LCVA, f. 384, ap. 3, b. 451, 1. 10 .

95 III PD 1939 m. kovo 2 d. įsakymas 6-ojo PP vadui. LCVA, f. 519, ap. 1, b. 383, 1. 69.

96 Kariuomenès štabo 1939 m. kovo 2 d. įsakymas. LCVA, f. 828, ap. 1, b. 197, 1. 1.

97 Kariuomenès štabo III skyrius, 1939 m. kovo 3 d., Nr. 31637. LCVA, f. 929. ap. 3, b. $848,1.177$.

98 Karo technikos viršininko 1939 m. kovo 10 d. raportas kariuomenès vadui. LCVA, f. 929. ap. 3, b. 1089, 1. 6 .

99 ŠR 1939 m. kovo 6 d. raportas. LCVA, f. 828, ap. 1, b. 197, 1. 2.

100 ŠR 2-osios tankų kuopos vado 1939 m. kovo 11 d. raportas. LCVA, f. 828, ap. 1, b. 197, 1. 6-6 apv. 1.

${ }^{101}$ III PD vado 1939 m. balandžio 14 d. raportas kariuomenès vadui. LCVA, f. 929, f. 9, b. 236, 1. 11-12 apv. 1 .
} 
rodyta nereikalingą karinị turtą išgabenti iš Klaipèdos „nesudarant evakuacijos ịspūdžio" ${ }^{102} .1939 \mathrm{~m}$. kovo $20 \mathrm{~d}$. kariuomenès vadas ịsakè ị Pagègių igulą ką tik pašauktų kareivių neskirti, o pačią igulą nuolatos laikyti visos sudèties ${ }^{103}$. Taigi Lietuvos kariuomenè 1939 m., reaguodama ì kylančią grèsmę, uostamiestyje stiprino savo karines pajėgas.

\section{LIETUVOS KARIUOMENĖS MOBILIZACIJA, KOVINĖ PARENGTIS IR IŠVEDIMAS}

Vokietijai ultimatyviai pareikalavus, nepaisant galiojančių sutarčių, kad Lietuva perduotų Klaipėdos kraštą Trečiajam reichui, įvykiai klostèsi labai greitai. 1939 m. kovo 21 d. 14.00 val. Kaune prasidejo Lietuvos vyriausybès posèdis. Jame dalyvavo ir A. Smetona, ir kariuomenės vadas brg. gen. S. Raštikis. Po J. Urbšio pranešimo, kaip rašè tuometis teisingumo ministras Jonas Gudauskis, kažkas iš ministrų „pasisakė už ginkluotą pasipriešinimą Reichui, pasipriešinimui užsitęsus bent porą savaičių gal issikištų kitos valstybės“. O ì prezidento klausimą, kiek ilgai Lietuva gali priešintis, krašto apsaugos ministras K. Musteikis ir kariuomenès vadas gen. S. Raštikis atsakè: „Nè trijų dienų.“ Posėdyje buvo nutarta: „Ministrų taryba, apsvarsčiusi susidariusią padètị ir nerasdama kitos išeities, laiko, kad ji priversta Vokietijos vyriausybès reikalavimą priimti <...>. Užsienio reikalų ministrui pavedama apie tai painformuoti Prancūzijos ir Didžiosios Britanijos igaliotus ministrus Kaune. " 104 Tad jau kovo 21 d., apie 22.10 val. vakaro, III PD vadas div. gen. M. Rèklaitis, Kaune iš kariuomenès vado gavęs įsakymą trauktis iš Klaipedos krašto, grịžo ị Šiaulius ir apie 22.30 val. telefonu pranešė 6-ojo ir 7-ojo PP vadams gen. št. plk. A. Breimeliui ir plk. P. Geniui, kad gautas įsakymas nedelsiant trauktis iš Klaipè-

${ }^{102}$ III PD vado įsakymas 6-ojo PP vadui. 1939 m. kovo 17 d. LCVA, f. 519, ap. 1, b. 383, 1. 70.

${ }^{103}$ III PD štabo I skyrius 7-ojo PP vadui. 1939 kovo 20 d. LCVA, f. 520, ap. 1, b. 350, 1. 38. ${ }^{104}$ Navickas, K. Lietuviu tautos savigynos patirtis. Lietuvos nepriklausomybès praradimo ir atgavimo istoriografine apžvalga (1938-1993). Vilnius, 2003, p. 28-29. 
dos krašto ${ }^{105}$. Taigi, kol Klaipėdos igulos vadas instruktavo šaulius, Kaune buvo priimtas sprendimas evakuotis. Vèliau per krašto apsaugos ministrą Klaipèdos igulos vadas gen. št. plk. A. Breimelis gavo A. Smetonos nurodymą: atvykus A. Hitleriui, būtina išvengti viešo susitikimo su juo ar jo palydovais, kad vokiečių propaganda nepasinaudotų tuo ir neskleistų gandų, jog lietuviai patys geruoju Klaipėdą Vokietijai perduoda ${ }^{106}$. Kovo $22 \mathrm{~d}$., apie 24.00 val., 6-ajame PP buvo pradèta evakuacija. 8.00 val. ryto prie pulko kareivinių susirinko antilietuviškai nusiteikusi minia ${ }^{107}$. Ryte, 7.00 val., i 7-ajji PP atvyko karininkas su oficialiu ịsakymu dèl dalinių iš Klaipèdos krašto atitraukimo. 8.00 val. kitas karininkas su analogišku ịsakymu atvyko ị Klaipèdą, i 6-ąj $\mathrm{PP}^{108}$. Taip pat 8.00 val. iš Tauragès ị Pagègius evakuacijos vykdyti buvo išsiųstas pulko I bataliono vadas mjr. Edvardas Kazanskis ir 4 sunkvežimiai, nors buvo apskaičiuota, kad reikès 6-ių ${ }^{109}$. Apie 9.00 val. Klaipedoje buvo iškabintos raudonos vèliavos su svastika ir Klaipèdos krašto vèliavos ${ }^{110}$. Nurodymas iškabinti vèliavas su svastika buvo duotas Vokietijos vyriausybès, jos Klaipėdos krašto susijungimo su reichu proga kabejo visą dieną ${ }^{111}$. 9.00-10.00 val. ị 6-ojo PP vadą kreipèsi Klaipėdos vyriausybinių įstaigų vadovai dèl evakuacijos, nes neturëjo jokių nurodymų ir informacijos, kaip elgtis ${ }^{112}$, bet iki vidurdienio visas šias Klaipèdos miesto įstaigas ir Jakų radijo stotị jau buvo užėmę SA būriai. I lietuvišką Ryto spaustuvę atėję SA vyrai pareiškè, kad darbas nutraukiamas, ir ją užrakino.

\footnotetext{
105 III PD vado 1939 m. balandžio 14 d. raportas kariuomenès vadui. LCVA, f. 929, f. 9, b. 236, 1. 11-12 apv. 1 .

${ }^{106}$ Musteikis, K. Prisiminimu fragmentai. Vilnius, 1989, p. 17.

107 6-ojo PP vado 1939 m. balandžio 3 d. raportas III PD vadui. LCVA, f. 929, f. 9, b. 236, 1. 13-14 apv. 1 .

${ }^{108}$ III PD vado 1939 m. balandžio 14 d. raportas kariuomenès vadui. LCVA, f. 929, f. 9, b. 236, 1. 11-12 apv. 1 .

109 7-ojo PP vado 1939 m. balandžio 7 d. raportas III PD vadui. LCVA, f. 929, f. 9, b. 236, 1. $15-15$ apv. 1.

${ }^{110}$ 6-ojo PP vado 1939 m. balandžio 3 d. raportas III PD vadui. LCVA, f. 929, f. 9, b. 236, 1. 13-14 apv. 1 .

${ }^{111}$ Apžvalga, 1939 m. kovo 27 d. LCVA, f. 648, ap. 1, b. 39, 1. 190.

112 6-ojo PP vado 1939 m. balandžio 3 d. raportas III PD vadui. LCVA, f. 929, f. 9, b. 236, 1. 13-14 apv. 1 .
} 
Išejo paskutiniai Lietuvos keleivio ir Vakarų numeriai ${ }^{113}$.

Pasienio policija ${ }^{114}$, negavusi jokios informacijos, SA būrių nuginkluota ir išsklaidyta, prie naujos valstybès sienos pradejjo rinktis tik kovo $23 \mathrm{~d}$. Per tą laiką naujos sienos apsauga rūpinosi 7-asis PP ir 3-iasis $\mathrm{KP}^{115}$, nors pasienio policijos pareigūno atsiminimuose teigiama, kad kovo $22 \mathrm{~d}$. gubernatūroje buvo gauta informacijos pasiruošti pasitraukti iš krašto, o naktị iš 22 i $23 \mathrm{~d}$. visiems pasienio policijos sektorių viršininkams išsiuntinètas slaptas ịsakymas apie padètị ir pasitraukimą prie naujos sienos, tad „pasienio policijos daliniai dienos būvyje tvarkingai pasitraukẻ ị nurodytus naujos sienos punktus" ${ }^{\text {"116. }}$. SA, nors ir nesèkmingai, bandè nuginkluoti Lietuvos karius ir užgrobti karinị turtą. Sunkvežimius, vykstančius su Lietuvos kariuomenès turtu iš Pagègių, SA sustabdè ir tik mjr. E. Kazanskiui pagrasinus granata atsitrauke $\dot{e}^{117}$. Kelyje iš Klaipèdos ị Kretingą SA būriai krètè civilius gyventojus, bandè sustabdyti ir karinị transportą, todèl lydintiems kariams teko šaudyti ị orą ${ }^{118}$. Lietuvos kariuomenè, nors ir vengdama konfrontacijos, buvo pasirengusi duoti atkirtị vietos ginkluotoms grupuotèms.

Ir centrinès valdžios įstaigos, ir civiliai gyventojai stokojo informacijos, galiausiai kovo 22 d., 8.00 val. ryto, Heilsbergo radiofonas viešai pranešè, kad Vokietijos ir Lietuvos vyriausybès susitarè dẻl Klaipėdos krašto perdavimo Vokietijai ir kad šis perdavimas ịvyks „dar tą pačią dieną“. Po pusvalandžio apie tai pranešè ir Kauno radijas. Tai buvo pirmasis oficialus prane-

\footnotetext{
${ }^{113}$ Vareikis, V. Klaipėdos krašto praradimas: tarp iliuzijų ir Realpolitik. Kultūros barai, 2009, Nr. 4 (533), p. 65.

${ }^{114} 1937$ m. gegužès $1 \mathrm{~d}$. duomenimis, Klaipèdos krašto pasienio policijoje tarnavo 505 asmenys: Klaipėdos krašto pasienio policijos dislokacija, $1937 \mathrm{~m}$. gegužès $1 \mathrm{~d}$. LCVA, f. 929 , ap. 3, b. $958,1.13$.

${ }^{115}$ III PD vado 1939 m. balandžio 14 d. raportas kariuomenès vadui. LCVA, f. 929, f. 9, b. 236, 1. 11-12 apv. 1 .

${ }^{116}$ Lietuvos policija istatymų ir tvarkos tarnyboje. Red. A. Bagdonas. Čikaga, 1974, p. 334-335.

117 7-ojo PP I bataliono vado 1939 m. kovo 22 d. raportas pulko vadui. LCVA, f. 929, f. 9, b. 236, 1. 16 .

${ }^{118}$ 6-ojo PP vado 1939 m. balandžio 3 d. raportas III PD vadui. LCVA, f. 929, f. 9, b. 236, 1. 13-14 apv. 1.
} 
šimas apie Klaipėdos krašto perdavimą ${ }^{119}$, tuo metu Lietuvos radiofonas ir kompetentingos įstaigos tylejo. Vyriausybè nenorejo leisti plisti gandams, tuo tikslu buvo net nutrauktas telefono ryšys, ir Klaipèdos gubernatūra neturejo tiesioginio telefono ryšio su Kaunu. Kovo 22 d., apie 9.00 val., virš Klaipedos gana žemai praskrido keli lèktuvai, ant kurių aiškiai buvo matyti Vokietijos simboliai. Tai buvo pirmasis oficialus Vokietijos pasveikinimas $^{120}$. Ordnungsdienstas ir SA užèmè centrinès valdžios įstaigas ${ }^{121}$, o Klaipèdos mieste kilo visuotinė panika, žmonès bandè atsiimti iš bankų indelius, bet po kelių valandų pinigų išdavimas buvo ị̌saldytas. Telefonas mieste dèl perkrovos neveikè. Gubernatoriui, apie pietus pasiekus Kauną, buvo pasakyta, kad „Klaipèdos evakuacijos reikalu nieko negalima padèti, nes viršūnèse taip pat esanti panika“. Veltui buvo mėginama susisiekti ir su kariniais daliniais Žemaitijoje, stengiantis gauti sunkvežimių evakuacijai atlikti. Geležinkelio stotyje susidarè didžiulè spūstis, nors geležinkeliai buvo vienintelè struktūra, kuri per sumaištị veikẻ ir visus norinčius vežè ì Didžiąją Lietuvą ${ }^{122}$. Apskritai 1939 m. kovą iš Klaipẻdos pasitraukẻ apie 11-15 tūkst. gyventojų, nors tiksliai statistiškai nustatyti atbejgèlių, tarp kurių buvo ir lietuvininkų, skaičiaus neịmanoma ${ }^{123}$.

Neturèdama tikslios informacijos dèl Vokietijos kariuomenès pasirodymo laiko, paskubomis kovo $21 \mathrm{~d}$. 13.45 val., išgabenus tik dalị turto, iš Pagėgių išvyko 7-ojo PP dviratininkų kuopa. 16.00 val. į Klaipedą atvyko sunkvežimiai iš Kretingos ir Telšių evakuoti karinio turto ${ }^{124}$. Tuo metu Kaune nuo 9.00 val. posèdžiavo Lietuvos vyriausybè. Ji nusprendè, kad

\footnotetext{
${ }^{119}$ Nors Švedijos radiofonas apie Vokietijos ultimatumą Lietuvai perduoti Klaipèdos kraštą pranešè naktį iš kovo 20 ị 21 d., o kitos užsienio radijo stotys nuolat kartojo šią žinią.

${ }^{120}$ Anysas, M. Kova dèl Klaipédos: atsiminimai 1927-1939. Chicago, 1978, p. 384-386.

${ }^{121}$ Lietuvos policija įstatymų ir tvarkos tarnyboje. Red. A. Bagdonas. Čikaga, 1974, p. 335.

122 Anysas, M. Kova dèl Klaipédos: atsiminimai 1927-1939. Chicago, 1978, p. 387-388.

1231939 m. gegužès 1 d. buvo užregistruotas 10231 atbėgèlis (8 924 lietuviai ir 1307 žydai), tačiau kai kurie asmenys, studentai, perkelti valdininkai ir pan., nebuvo registruoti kaip atbėgèliai. Kai kada nurodoma, kad iš Klaipèdos krašto pasitraukẻ apie 18-20 tūkst. asmenų. Žr.: Arbušauskaitè, A. Lietuvos optantai: klaipédiškiai, 1939. Klaipėda, 2001, p. 22.

${ }^{124}$ III PD vado 1939 m. balandžio 14 d. raportas kariuomenès vadui. LCVA, f. 929, f. 9, b. 236, 1. 11-12 apv. 1 .
} 
taikiu būdu išlaikyti Klaipèdos nepavyks ir kraštas bus perduotas Vokietijai. Taip pat svarstė „sustiprintos apsaugos“ valstybeje įvedimo klausimą, Respublikos Prezidento buvo prašoma nuo kovo $22 \mathrm{~d}$. paskelbti Lietuvoje „sustiprintą apsaugą“. Buvo aptarta galimybė pareikšti oficialų protestą dèl Vokietijos agresijos ${ }^{125}$. Kovo $22 \mathrm{~d}$. vakare, 18.00 val., ìvyko antrasis vyriausybès posedis, kuriame buvo svarstomi Žemės banko išduotų paskolų, išperkamųjų mokesčių ir melioracijos skolų mažinimo klausimai ${ }^{126}$. Tuo metu Lietuvos užsienio reikalų ministro J. Urbšio lèktuvas apie 18.00 val. nusileido Berlyno Tempelhofo oro uoste ${ }^{127}$. Regis, vyriausybė susitaikè su praradimu ir, užuot èmusi koordinuoti evakuaciją iš Klaipėdos, pradèjo svarstyti einamuosius vidaus paskolų klausimus.

1939 m. kovą, traukiantis iš Klaipedos, anot plk. J. Andrašūno, „reikejjo vadovautis šaltu protu. Dieną ir naktị visi komendantūros ir mūsų buto pečiai buvo kūrenami. Skubiai naikinome įvairias bylas, kad neįkliūtų ar nenukentètų daug nekaltų žmonių. <...> Mūsų vienas didelis kambarys buvo prikrautas šautuvų šauliams, kurių neteko panaudoti. Anksti ryte

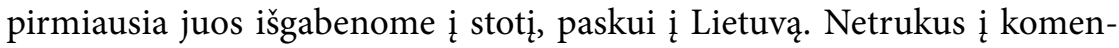
dantūrą ir ị mūsų butą ịsiveržè uniformuoti hitlerininkai $<\ldots>$. Vieną hitlerininką pavaišinau angliškomis cigaretèmis. Jis man sako: - Ačiu! / - Tai tu moki lietuviškai? / - Kaip gi, juk aš tarnavau 4 pèstininkų pulke Panevèžyje - Pajuostèje. Kartais mane nuveždavot ị pulką. / - Tai kaip jūs su jais susidejote? / - O ką darysi, dirbu restorane, ten visi priklauso, aš nenoriu nukentèti, išsiskirti..."128

Kovo 22 d., apie 18.00 val., komendantas plk. J. Andrašūnas paliko Klaipėdos komendantūrą ir išvyko ị 6-ąji $\mathrm{PP}^{129}$.

Lietuvos kariuomenès daliniams davusi įsakymą trauktis iš Klaipedos krašto, karinè vadovybė nedelsdama èmėsi ịvairių karinių pajėgų stiprini-

\footnotetext{
${ }^{125}$ Ministrų Tarybos posèdžio protokolas. 1939 m. kovo 22 d. LCVA, f. 923, ap. 1, b. 1080, 1. 48-48 apv. 1 .

126 Ten pat, 1. 50-50 apv. 1 .

${ }^{127}$ Vareikis, V. Klaipėdos krašto praradimas: tarp iliuzijų ir Realpolitik. Kultūros barai, 2009, Nr. 4 (533), p. 65.

${ }^{128}$ Andrašūnas, J. Klaipeda - 1938-1939-ieji. Kardas, 1991, Nr. 3, p. 27.

${ }^{129}$ Klaipèdos krašto komendantūros komendanto $1939 \mathrm{~m}$. balandžio $5 \mathrm{~d}$. raportas III PD vadui. LCVA, f. 929, f. 9, b. 236, 1. 17-18.
} 
mo priemonių. $1939 \mathrm{~m}$. kovo 22 d. 15.00 val. ì Tauragę išvyko ltn. Albino Repšio vadovaujamas tankų būrys (5 tankai, sunkvežimis ir motociklas) ir 18 kareivių ${ }^{130}$, ị paskyrimo vietą - Tauragę - ŠR 2-osios kuopos tankų būrys atvyko kovo $22 \mathrm{~d}$. 18.00 val. ${ }^{131}$ Lietuvos vyriausybè, bijodama neramumų, paskelbė sustiprintos apsaugos padetį visoje Lietuvoje, išskyrus Klaipedos, Šilutès ir Pagègių apskritis ${ }^{132}$. Be to, nusprendè visus karo prievolę atliekančius nuolatinius Klaipèdos krašto gyventojus paleisti iš kariuomenès. Susidariusị karių trūkumą buvo ketinta kompensuoti anksčiau pašaukiant $1939 \mathrm{~m}$. pagal planą numatytus atsargos karius. I kariuomenę iš Klaipedos krašto kasmet buvo pašaukiama apie 800, o vienu metu - iki 1200 vyrų $^{133}$. Buvo paleisti 333 šauktiniai, pradejję tarnybą $1938 \mathrm{~m}$. gegužès 1 d., ir 452 šauktiniai, pradejję tarnybą $1938 \mathrm{~m}$. spalio 1 d. ${ }^{134}$

$1939 \mathrm{~m}$. kovo $22 \mathrm{~d}$. Lietuvoje buvo paskelbtas ir vyko atsargos karių šaukimas i pratybas - „karo pratimus“135. Jų metu pašaukti kariai turèjo pakeisti iš Klaipedos krašto kilusius vyrus ${ }^{136}$. Informacija apie būsimus karo pratimus tradiciškai ${ }^{137}$ buvo paskelbta viešai ir iš anksto Karyje 1939 m. sausio 26 d., tačiau skelbime šaukimo data nenurodyta. Atsargos karininkai ir puskarininkiai karo pratimų atlikti turejjo būti šaukiami 4, o grandiniai ir eiliniai - 3 savaitèms. Šaukiamieji privalèjo gauti raštiškus šaukimus, kuriuose pateikta smulkesnè informacija ${ }^{138} .1939 \mathrm{~m}$. kovo $22 \mathrm{~d}$. Lietuvoje buvo paskelbtas šaukimas ir i ypatinguosius karo pratimus,

\footnotetext{
130 ŠR 1939 m. kovo 25 d. raportas. LCVA, f. 828, ap. 1, b. 197, 1. 8.

${ }^{131}$ Ltn. A. Repšio 1939 kovo 26 d. raportas pulko vadui. LCVA, f. 520, ap. 1, b. 350, 1. 42. 132 Navickas, K. Lietuviu tautos savigynos patirtis. Lietuvos nepriklausomybès praradimo ir atgavimo istoriografinè apžvalga (1938-1993). Vilnius, 2003, p. 29.

${ }^{133}$ Paleisti iš kariuomenès Klaipèdos krašto vyrai. Karys, 1939, kovo 23, Nr. 12 (1032), p. 381.

134 [Dokumentas be pavadinimo] 1939 m. LCVA, f. 929, ap. 5, b. 563, 1. 68.

${ }^{135}$ Atsargos ir apsaugos karių šaukimą i karo pratimus skelbdavo krašto apsaugos ministras. Atsargos kariai galejo būti šaukiami ị 6 savaičių trukmès karo pratimus iki 3 kartų: Karinès prievolès įstatymas. Vyriausybès žinios, 1936, birželio 30, Nr. 538, p. 9.

${ }^{136}$ KAM iqsakymas kariuomenei. 1939 m. kovo 22 d. Nr. 19. LCVA, f. 981, ap. 1, b. 1, 1. 22. ${ }^{137}$ Apie planuojamus karo pratimus viešai buvo skelbiama ir ankstesniais metais: Karo pratimai atsargos kariams. Karys, 1937 m. Nr. 12, p. 342.

${ }^{138}$ Skelbime buvo išvardytos visos karininkų ir karių grupès, kurios 1939 m. turèjo būti pašauktos karo pratimų atlikti: Kariuomenès štabo pranešimas atsargos karių karo pratimų reikalu. Karys, 1939 m. Nr. 4, p. 114.
} 
o iš gyventojų rekvizuojami arkliai ir transporto priemonès. Dokumente, kurị pasirašė Kariuomenės štabo viršininkas ir III skyriaus viršininkas, kovo $22 \mathrm{~d}$. vykę ypatingieji karo pratimai ịvardijami kaip mobilizacija, kuri vykdoma pagal mobilizacijos direktyvą ir tvarkaraščius. Tikslus pašauktų žmonių ir dalinių, ł kuriuos jie šaukti, skaičius kol kas nenustatytas, tačiau esami dokumentai leidžia teigti, kad šaukimas apėmė iš esmès visą Lietuvą (dokumente minimos Trakų, Šakių, Ukmergès, Vilkaviškio apskritys, Kaunas ir kiti apskričių miestai), taip pat kad kariai buvo šaukiami i 1-ajj KP, 1-ąj ̨ PP, I inžinierių batalioną, atsargos kariai vyko ị igulas, esančias ¿vairiose šalies vietose ${ }^{139}$. Vilkaviškio apskrityje ypatinguju karo pratimų metu mažiausiai 29 asmenys gavo nurodymus pristatyti rekvizuojamą turtą arba arklius, iš jų 10, arba $32 \%$, prievolę atliko vèliau kaip per 24 val. Štai 1939 m. kovo 22 d. 16 val. seniūnas įsakè iš Simanèliškio dvaro ị 9-ąji PP pristatyti 8 vežimus, 8 arklius, 8 poras pakinktų ir balną ${ }^{140}$. Taigi apèmè visų divizijų mobilizacinius plotus ir skirtingas kariuomenès rūšis. $\mathrm{Ne}$ visose komendantūrose, savivaldybèse ir kariuomenès dalyse buvo pasirengta mobilizacijai ir vèluojama beveik visose srityse. Atsarginiai rinkosi ir transporto priemonès buvo gabenamos i Tauragès igulą net 5 dienas. Buvo tokių seniūnų, kurie nurodymą „tuojau“ suprato, kad, pavyzdžiui, vežimą reikia pristatyti per 24 val. ${ }^{141}$

Pagal 1937 m. patvirtintus mobilizacijos planus ypatingieji karo pratimai buvo numatyti viename iš kariuomenès mobilizacijos tvarkaraščių ${ }^{142}$. Be to, tiek skelbiant ypatinguosius karo pratimus, tiek mobilizaciją pagal tvarkaraštị Nr. 11, atsargos kariai turejjo gauti vienodus rožinès spalvos šaukimo ir raginimo lapelius ${ }^{143}$. Galima konstatuoti, kad 1939 m. kovo 22-24 d. ị ŠR 3-iąją tankų kuopą atvyko 61 atsargos karys, ị 2-ąją kuopą -

${ }^{139}$ Pastabos dèl 1939 m. kovo 22 d. ịvykusių ypatingų karo pratimų, 1939 m. birželio 13 d. LCVA, f. 929, ap. 5, b. 460, 1. 222-226.

${ }^{140}$ Dèl pil. Bačkevičiaus ir Montvilo skundų. 1939 m. birželio 2 d. LCVA, f. 929, ap. 5, b. $576,1.1$.

${ }^{141}$ Vaičenonis, J. Lietuvos kariuomenès modernizacija (1926-1939). Darbai ir dienos, 2000 , t. XXI, p. 161.

${ }^{142}$ Kariuomenès mobilizacijos reikalu [1940 m.]. LCVA, f. 929, ap. 5, b. 591, 1. 29.

${ }^{143}$ Mobilizacijai pagal tvarkaraštị Nr. 12 šaukimo ir raginimo lapeliai buvo balti, o pagal tvarkaraštị Nr. 4 - geltoni: Kariuomenès štabo 1939 m. rugsejjo 25 d. ịsakymo nuorašas. LCVA, f. 929, ap. 3, b. 848, 1. 221. 
50 atsargos karių, ì 4-ąją kuopą - 41 karys $^{144}$. Ypatinguju pratimų atlikti pašauktieji atsargos kariai balandžio $1 \mathrm{~d}$. buvo paleisti ${ }^{145}$. Panašaus pobūdžio kaip 1939 m. kovo 22 d. ypatingieji karo pratimai vyko ir $1939 \mathrm{~m}$. rugsėjo pradžioje, prasidejus Vokietijos ir Lenkijos karui ${ }^{146}$. Taigi minètus Lietuvos kariuomenès veiksmus galima vadinti slapta daline mobilizacija, kai, prisidengiant pratybomis, manevrais ar kt. veiksmais, siekiama užtikrinti jos organizavimo ir vykdymo slaptumą. Teigtina, kad vienu metu vyko du atsargos karių šaukimai: ị karo pratimus, kad pakeistų iš Klaipèdos krašto kilusius ir iš kariuomenès paleistus karius, ir ì ypatinguosius karo pratimus, kad sustiprintų karinius dalinius.

Vykstant evakuacijai Klaipèdos igulai trūko transporto priemonių turtui ị traukinių vagonus gabenti, ji turèjo tik keletą vežimų ir vieną sunkvežimi. Be to, karius trikdè aplinkui kareivines susirinkusi minia vietos vokiečių, kurie juokèsi, įžeidinèjo ragindami: „Greičiau nešdinkitès, nes bus jums blogai, jau ateina Adolfas." Pulko karininkams ir puskarininkiams rūpinantis karinio ir šeimų turto, kuris buvo gabenamas kartu, krova į vagonus, „kareiviai pasijuto laisvesni. Išliedami savo pyktị, jie išmušė vieną kitą langą ir atsuko kareivinèse vandens kranus, bet po įspejjimo vyrai nusiramino ir laukè, kas bus toliau. " ${ }^{147}$ Itampą didino ir tai, kad i pačių kareivinių teritoriją du kartus buvo įsiveržusi minia priešiškai nusiteikusių gyventojų ir kariams juos teko išstumti jèga. Pulke nuolat budejo sustiprinta apsauga, kulkosvaidžiai buvo parengti kovai ${ }^{148}$. Vienu metu kariai imitavo kareivinèse gaisrą po iš čiužinių iškratytais šiaudais patalpose pakišę dūminę granatą. Pro langus pradèjus rūkti dūmams atskubejjo miesto gaisrininkai. Puskarininkis Kazys Leknickas prisiminè, kad, lydint ị geležinkelio stotị gurguolę su igulos turtu, jis neatlaikè ịtampos ir vaikè pakeliui pasi-

\footnotetext{
144 ŠR atvykusių atsargos karių sąrašai. 1939 m. kovas. LCVA, f. 828, ap. 1, b. 200, 1. 4-10. 145 ŠR pašauktų atlikti karo pratimų ir paleistų $\mathfrak{i}$ atsargą sąrašai, $1939 \mathrm{~m}$. balandžio $1 \mathrm{~d}$. LCVA, f. 828, ap. 1, b. 200, 1. 35-37 apv. 1.

146 Vykdant pasirengimų eilę. Kariuomenès štabo I skyriaus referatas, 1939. LCVA, f. 929, ap. 3, b. 1079, 1. 12 .

${ }^{147}$ Leknickas, K. 6 pèst. pulko pasitraukimas iš Klaipèdos. Karys, 1964, sausis, Nr. 1 (1398), p. 10.

${ }^{148}$ 6-ojo PP vado 1939 m. balandžio 3 d. raportas III PD vadui. LCVA, f. 929, f. 9, b. 236, 1. 13-14 apv. 1 .
} 
tyčioti iš besitraukiančių Lietuvos karių susirinkusius vietos vokiečius ${ }^{149}$. Kovo 22 d., apie 17.00 val., pas 6-ojo PP vadą atvyko civiliais drabužiais apsirengęs Vokietijos armijos kapitonas tartis dèl kareivinių perdavimo, buvo sutarta kareivines perduoti kovo 23 d. 8.00 val. ${ }^{150}$

Iki 21.00 val. 6-ojo PP kariai geležinkelio stotyje prikrovè per 80 vagonų karinio turto, bet sąstatas negalejo išvykti, nes nebuvo garvežio, kurị Klaipèdos geležinkelininkai vokiečiai specialiai užlaikè. Lietuvos kariams buvo nurodyta Klaipedą palikti ne vèliau kaip kovo 23 d. 3.00 val. nakties. Tik iš Kretingos atsiuntus garvežị ir pulko vadui pagrasinus panaudoti karinę jègą, kovo 23 d. 2.30 val. sąstatas su kariniu turtu pajudejo iš Klaipedos i Kretingą ${ }^{151}$. Jis buvo apšaudytas iš šautuvų, tačiau nuostolių nepatyré ${ }^{152}$. Tą pačią naktị, 2.45 val., Klaipedą kartu su komendantūros personalu paliko 6-asis PP. Jis 7.40 val. be incidentų per 5 valandas, pėsčiomis nužygiavęs apie $17 \mathrm{~km}$, kirto Klaipėdos krašto ir Didžiosios Lietuvos sieną ir sustojo Kretingoje ${ }^{153}$. Visą kelią iš paskos, kartais vos $300 \mathrm{~m}$ atstumu, mašinomis važiavo vokiečių būrys ${ }^{154}$. Lietuvos karius, atvykusius i Kretingos geležinkelio stotị, pribloškè vaizdas - lyg karas būtų prasidėjęs: minia žmonių, verkiantys vaikai, baldai, patalynè, indai, ịvairūs ryšuliai ir ryšulèliai buvo sumesti po atviru dangumi gatvejje, ant perono, gretimame darže ir t. t. ${ }^{155}$ Išvedami Lietuvos kariai be poilsio ir miego triūsė dvi paras, jie po naktinio žygio į Žemaitiją buvo visiškai išsekę, kai kurie vos laikèsi ant kojų, tačiau rikiuotę palikti atsisakè, dalinio nuotaikos buvo liūdnos, bet karingos. Naujajame pasienyje buvo paliktas apsaugos būrys su dviem

\footnotetext{
${ }^{149}$ Leknickas, K. 6 pèst. pulko pasitraukimas iš Klaipėdos. Karys, 1964, sausis, Nr. 1 (1398), p. 10.

${ }^{150}$ Kariuomenès štabo II skyrius, žinios iki 1939 m. kovo 22 d. 18 val. LCVA, f. 929, ap. 2, b. $1068,1.9$.

${ }^{151}$ III PD vado 1939 m. balandžio 14 d. raportas kariuomenès vadui. LCVA, f. 929, f. 9, b. 236, 1. 11-12 apv. 1 .

${ }^{152}$ Kariuomenès štabo II skyrius, žinios nuo 1939 m. kovo 22 d. 18 val. iki kovo 23 d. 07.00 val. LCVA, f. 929, ap. 2, b. 1068, 1. 10.

${ }^{153}$ III PD vado $1939 \mathrm{~m}$. balandžio 14 d. raportas kariuomenès vadui. LCVA, f. 929, f. 9, b. 236, 1. 11-12 apv. 1 .

${ }^{154}$ 6-ojo PP vado 1939 m. balandžio 3 d. raportas III PD vadui. LCVA, f. 929, f. 9, b. 236, 1. 13-14 apv. 1.

${ }^{155}$ Iš Klaipėdos bėgant. Verslas, 1939, balandžio 8, Nr. 14 (392), p. 4.
} 
sunkiaisiais kulkosvaidžiais. Pulkui išvykstant iš kareivinių, du karininkai buvo pasiųsti ị Klaipẻdos krašto gubernatūrą, kad kareivines perduotų direktorijai ir informuotų apie Lietuvos kariuomenès ịgulos išvykimą. Direktorija vẻlavo atsiųsti policininkus, kurie turejo užtikrinti kareivinių apsaugą, tad kai kovo 23 d. 8.00 val. ryto Klaipedos miesto policininkai atvyko, kareivinèse jau seniai šeimininkavo minia ${ }^{156}$. Panašiai ịvykiai klostèsi Pagègiu iguloje - ten likęs vienas Lietuvos karininkas turèjo kareivines perduoti Vokietijos kariuomenei, tačiau 22 d., apie 17.00 val., ị jas įsiveržè apie 300 vietinių Ordnungsdiensto narių ir norejo išgrobstyti likusị turtą, taigi ten likęs karininkas buvo priverstas derètis ${ }^{157}$. Buvusių pasienio policijos objektų perdavimu ir likusių policininkų šeimų evakuacija rūpinosi pasienio policijos komisaras V. Remeikis ${ }^{158}$.

Su sunkumais susidūrè ir karo laivo Prezidentas Smetona igula, nes, netekus vienintelio tinkamo stovèti uosto, kurị laiką buvo priversta plaukioti tarp Šventosios ir Liepojos. Apsistojęs pradètame rengti Šventosios uoste laivas buvo užblokuotas, nes jūra smèliu užnešè ekvatorių ${ }^{159} .1939$ m. kovo 23 d., ryte, Klaipèdos uoste pasirode juodomis uniformomis vilkintys SA būrio nariai ir pradejo užimti prekybos laivus. Pamatę i juos nukreiptus Lietuvos karo laivo kulkosvaidžius, jie sustojo ${ }^{160} .1939 \mathrm{~m}$. karo laive tarnavęs liudininkas prisiminè, kad 23 d. rytą mieste kaukè sirenos, o ant namų plevésavo raudonos vèliavos su svastika. Laivo kapitonui nuolat užimtomis telefono linijomis nepavyko susisiekti su Kaunu, o trūkstant karių nebuvo galima uždaryti uosto ir apsaugoti valstybinių laivų. Apie bręstančius įvykius karo laivo kapitonas neturèjo jokios informacijos, nors jau išvakarèse laivo karininkas pažymėjo, kad SA nariai geležinkelio stotyje smurtavo prieš žydus, bėgančius ị Lietuvą. Kovo 23 d. ryte būrys SA narių užèmẻ laivus Perkūnq ir Jūratę, o nuo karo laivo atsitraukè, pamatę kulkosvaidžius. Vèliau atvykęs karo technikos karininkas informavo, kad apie 10.00 val.

\footnotetext{
${ }^{156}$ 6-ojo PP vado 1939 m. balandžio 3 d. raportas III PD vadui. LCVA, f. 929, f. 9, b. 236, 14-14 apv. 1.

${ }^{157}$ Kariuomenès štabo II skyrius, žinios iki 1939 m. kovo 22 d. 18 val. LCVA, f. 929, ap. 2, b. $1068,1.9$.

${ }^{158}$ Lietuvos policija įstatymų ir tvarkos tarnyboje. Red. A. Bagdonas. Čikaga, 1974, p. 335.

${ }^{159}$ Surgailis, G. Lietuvos karinis laivynas 1935-1940 m. Vilnius, 2003, p. 44-48.

${ }^{160}$ Surgailis, G. Lietuvos karo laivynui - 60 metų. Karys, 1995, Nr. 7, p. 27.
} 
ryto su A. Hitleriu atplauks Vokietijos karo laivų eskadra. Karo laivas Prezidentas Smetona ir pasienio policijos laivai paliko Klaipėdą. Kartu i jūrą išplaukè ir Lietuvos prekybos laivai Kaunas, Marijampolè, Šiauliai ir kt. ${ }^{161}$

Kovo 22-23 d. visi Lietuvos kariuomenès daliniai, gavę Lietuvos vyriausybès ịsakymą, iš Klaipėdos krašto skubiai pasitraukè. Kaip vèliau savo raportuose konstatavo 6-ojo ir 7-ojo PP vadai ir Klaipedos krašto komendantas, evakuacija iš Klaipèdos vyko chaotiškai, niekas laiku negaudavo aiškios informacijos ir nurodymų. Kariniam turtui išvežti trūko transporto, o pažadètasis neatvykdavo arba vèluodavo. Lietuvos vyriausybė nebekontroliavo padèties nei mieste, nei krašte ${ }^{162}$. Tuo metu Plungèje stovèjęs 6-ojo PP II batalionas buvo kovinès parengties - pasiruošęs reaguoti Ł̇ nenumatytus ịvykius ${ }^{163}$, o Plungès stotis atrodè lyg Rytų turgus - jame šurmuliavo pabègèlių žydų minia ${ }^{164}$.

1939 m. kovo 23 d. minètam R. Bèkštai atẻjus ị Vytauto Didžiojo gimnaziją, jos direktorius Kazys Trukanas visiems pranešè, kad Klaipèda perduodama Vokietijai ir pamokų nebus. Šeima skubiai susikrovė daiktus. Berniuko atmintyje užsifiksavo, kad „per porą valandų bute [buvo] tuščia, mes sẻdamès ant savo daiktų ir išvažiuojame plentu ị Kretingą. Pakeliui pralenkiam iš Klaipèdos išeinančios Lietuvos kariuomenès pulką" ${ }^{165}$. Buvęs Klaipedos krašto gubernatūros tarnautojas V. Bakūnas, apibūdindamas Lietuvos ịstaigu pasitraukimą iš Klaipèdos, rašè:

„Dieną ar dvi prieš Hitleriui atvykstant Klaipėdon <...> gubernatūroje buvo likęs tik vienas kitas aukštesnis valdininkas. <...> 1939 m. kovo 23 d. praejo vokiečių aukščiausio entuziazmo, demonstruojančio vokišką patriotizmą, ženkle. <...> Klaipėdoje ir krašte per vieną dieną gyvenimas pasikeitè kaip diena ir naktis: vokiečiams atsivèrè naujas rytojus, lietuviams -

\footnotetext{
${ }^{161}$ Laivas be uosto. Karys, 1992, Nr. 10, p. 13.

${ }^{162}$ Klaipėdos krašto komendantūros komendanto $1939 \mathrm{~m}$. balandžio 5 d. raportas III pèstininkų divizijos vadui Nr. 268. LCVA, f. 929, f. 9, b. 236, 1. 17-18; 6-ojo péstininkų pulko vado $1939 \mathrm{~m}$. balandžio 3 d. raportas III pèstininkų divizijos vadui Nr. 424. LCVA, f. 929, f. 9, b. 236, 1. 13-14 apv. 1; 7-ojo pèstininkų pulko vado $1939 \mathrm{~m}$. balandžio 7 d. raportas III pèstininkų divizijos vadui Nr. 338. LCVA, f. 929, f. 9, b. 236, 1. 15-15 apv. 1.

${ }^{163}$ Listopadskis, J. Laisves ir vergovés metai. Vilnius, 1993, p. 57.

${ }^{164}$ Iš Klaipėdos bėgant. Verslas, 1939, balandžio 8, Nr. 14 (392), p. 4.

${ }^{165}$ Bèkšta, R. Gyvenimas Malkų gatveje. Atsiminimai apie tarpukario Klaipèdą. Vilnius, 2015, p. 167-168.
} 
diena tapo naktimi. <...> Kovo 24 d. rytą vogčiomis žvilgtelejjau pro salono langą i Palangos g. Matau - 3 ar 5 pusiau karinio naudojimo atviri automobiliai, prie jų stovi po du gestapininkus ir po kelis civilius, sakyčiau, ūkininkus, dèvinčius sermėgomis. Tų „sermėgių“ tarpe atpažinau buvusị Vanagų šaulių būrio vadą Pèteraitị, prieš kelis metus nušovusį vokiečių autonominès valdžios policininką, mèginusị jị nuginkluoti kaip šaulių būrio vadą. Kitas „sermègius“ - Klimkaitis, buvęs šaulių pirmininkas, dar pora kitų lyg ir pažįstamų veidų. "166

1939 m. kovą buvo pasiektas šaulių kovos Klaipèdos krašte finalas. 1939 m. kovo 20 d. Klaipėdoje, komendantūroje, komendanto plk. J. Andrašūno ir 6-ojo PP vado gen. št. plk. Antano Breimelio susitikime su šaulių būrių vadais buvo aptarta sudètinga situacija ir pateikta informacija, kad vyriausybė yra nusiteikusi panaudoti karinę jègą ${ }^{167}$. Kovo $21 \mathrm{~d}$. spaudoje, kaip iprasta, buvo paskelbta, kad Uosto kuopos šauliai i mokymus turès rinktis net kovo $22 \mathrm{~d}$. 18.00 val. Malkų g., prie pasienio policijos ${ }^{168}$. Žinoma, tokius mokymus galima vertinti kaip šaulių rengimąsi pavojaus atvejui ir sieti su vyriausybès priimtais sprendimais, taip pat Klaipėdoje vykusiais igulos vado ir šaulių būrių pasitarimais. Tačiau šių publikuotų šaltinių išorinė kritika ir jau minèti faktai apie šaulių padètį Klaipėdos krašte kelia abejonių ir klausimų dèl XX rinktinès panaudojimo ginkluoto konflikto atveju galimybių ir perspektyvų. Kovo $21 \mathrm{~d}$. vakare Klaipèdos komendantūroje vèl vyko pasitarimas su LŠS Klaipèdos būrių vadais. Jo metu vadai buvo ispèti nepradèti veikti be komendanto nurodymo ${ }^{169}$, o XX rinktinès vadas paprašè gen. št. plk. A. Breimelio, 6-ojo PP vado, rinktinei papildomai išduoti 16 šautuvų, 1 lengvajji kulkosvaidị ir 3490 šovinių ${ }^{170}$. Tačiau naktị iš 21 ị $22 \mathrm{~d}$. Klaipèdos miesto šauliai buvo nuginkluoti ${ }^{171}$. Klaipedos igulos vadas gen. št. plk. A. Breimelis neturejo naujų

\footnotetext{
166 Bakūnas, V. Fašistinė letena virš Klaipèdos. Kardas, 1995, Nr. 1-2, p. 34-35.

${ }^{167}$ Klaipedos krašto komendantūros komendanto $1939 \mathrm{~m}$. balandžio $5 \mathrm{~d}$. raportas III PD vadui. LCVA, f. 929, ap. 9, b. 236, 1. 17-18.

168 Pranešimai Klaipėdos šauliams. Vakarai, 1939, kovo 21, Nr. 67 (977), p. 8.

${ }^{169}$ Klaipedos krašto komendantūros komendanto $1939 \mathrm{~m}$. balandžio $5 \mathrm{~d}$. raportas III PD vadui. LCVA, f. 929, ap. 9, b. 236, 1. 17-18.

${ }^{170}$ XX Klaipedos šaulių rinktinès 1939 m. raštų registracijos knyga. LCVA, f. 561, ap. 2, b. 4544 , apv. 1.79.

${ }^{171}$ 6-ojo PP vado 1939 m. balandžio 3 d. raportas III PD vadui. LCVA, f. 929, f. 9, b. 236,
} 
nurodymų, o iš anksto parengti pasitraukimo planai liko neigyvendinti šauliai laikinai turejjo perimti miesto kontrolę ir saugoti svarbius objektus, bet buvo nuginkluoti. Vèliau raporte, kuris kartu su komendanto, 7-ojo PP ir III PD vadų raportais buvo išsiųstas kariuomenès vadui ${ }^{172}, 6$-ojo PP vadas gen. št. plk. A. Breimelis konstatavo: „XX šaulių rinktinè buvo laikoma kaip reali pajèga Klaipėdos krašte. Reikalui esant, jai buvo numatyti operatyviniai uždaviniai - saugoti Centro Valdžios ịstaigas. Pasitikèti kaip realia pajèga šiuo kritišku momentu pasirodè didžiulè klaida. Šaulius prisièjo nuginkluoti iš III. 21 ị 22 d. naktị. Jų ginklai buvo pergabenti ị kareivines. "173 Taigi Lietuvos karinès pajègos Klaipėdoje gerokai sumažèjo, o iš 6-ojo PP skirti dali karių patruliuoti mieste ar saugoti strateginių objektų neturèta galimybių - igula nebuvo tokia gausi, kad būtų galima skaidyti jègas. Klaipẻdos krašto komendantūra taip pat liko be apsaugos, jos turtui nugabenti i geležinkelio stotị pavyko iš AB Maistas gauti porą sunkvežimių, o Krašto direktorija pažadejo lydeti po miestą ir apylinkes išsibarsčiusius šaulius ị kareivines, kad atiduotų ginklus ${ }^{174}$. Tačiau SA vyrai, tarp jų net ir tarnavę Lietuvos kariuomeneje, įsiveržè ị Klaipèdos komendantūrą ir pareikalavo, kad komendantas atiduotų ginklus, draude išvežti bet kokị turtą ${ }^{175}$. Panašiai kovo 22 d. 9.20 val. Šilutès miesto policijos komisaras su SA vyrais, darydami kratą geležinkelio namuose, konfiskavo rastus 26 šautuvus ir kt. ginklus ${ }^{176}$. Lauksargių šaulių būrị taip pat nuginklavo SA ${ }^{177}$. Buvęs Rusnès

1. 13-14 apv. 1.

172 III PD vado 1939 m. balandžio 14 d. raportas kariuomenès vadui. LCVA, f. 929, f. 9, b. 236, 1. 11-12 apv. 1 .

${ }^{173}$ 6-ojo PP vado 1939 m. balandžio 3 d. raportas III PD vadui. LCVA, f. 929, f. 9, b. 236, 1. 13-14 apv. l; Visas dokumentas publikuotas, žr.: Vareikis, V. Pasitraukimas iš Klaipèdos. Klaipédos krašto aneksija 1939 m.: politiniai, ideologiniai, socialiniai ir kariniai aspektai (Acta Historica Universitatis Klaipedensis, t. XXI). Sud. S. Pocytè. Klaipèda, 2010, p. 221-225.

${ }^{174}$ Arbušauskaitė, A. L. Anšliusas ir Klaipèdos krašto gyventojai (1939-1944). Klaipèda, 2010, p. 64.

${ }^{175}$ Klaipeddos krašto komendantūros komendanto $1939 \mathrm{~m}$. balandžio 5 d. raportas III PD vadui. LCVA, f. 929, f. 9, b. 236, 1. 17-18.

${ }^{176}$ XXII rinktinès 22-ojo Šilutès stoties būrio šaulio $1939 \mathrm{~m}$. balandžio $20 \mathrm{~d}$. raportas. LCVA, f. 561, ap. 2, b. 4532, 1. 475.

177 7-ojo PP vado raportas III PD vadui. 1939 m. kovo 27 d. LCVA, f. 520, ap. 1, b. 350, 1. 44 . 
šaulys raporte teigè, kad Vokietijai užimant Klaipèdos kraštą apie 48 val. buvo valdžios vakuumas, kai valde SA ir Ordnungsdiensto gaujos. Rusnès šaulių būrio vado kovo $22 \mathrm{~d}$. jau nebuvo, būrio šauliai jokių nurodymų nebuvo gavę, o jo pavaduotojas apie 11.00 val., paklaustas, kaip elgtis su turimu šautuvu, atsakè: „Daryk, kaip nori.“ Iki to laiko dalis šaulių ir pasienio policininkų jau buvo nuginkluoti. I minèto šaulio namus atejo 4 SA vyrai, 2 iš jų anksčiau priklausè Santaros organizacijai. Šauli, kuris šautuvą slèpe், sumušè, teigdami, kad turi sąrašus šaulių, kurie laiko ginklus, kratos metu jie rado ir atemé šautuvą, durtuvą ir 45 šovinius ${ }^{178}$. Kovo $22 \mathrm{~d}$., apie 14.00 val., SA suėmė Panemunès muitinès viršininką ir keletą valdininkų, atèmè $30000 \mathrm{Lt}^{179}$.

Ginklų „konfiskavimo“ atvejų Klaipėdos karšte buvo ne vienas, o Latvijos generalinis konsulas Klaipėdoje Jānis Seskis pranešime savo vyriausybei rašè: „Girdejjau, kad daugelis Klaipèdos krašto šaulių pabėgo ị Didžiąją Lietuvą, nes jiems grèsẻ Vokietijos ir vokiečių susidorojimas." ${ }^{180}$

Vokiškos, kai kurios - sukarintos, Klaipėdos krašto organizacijos vienijo apie 60000 narių, tad Lietuva krašte neturejo ką prieš juos pastatyti, nebent palyginti „negausius Šaulių sąjungos narius, kurie jautè augančią vokiečių neapykantą “181. 1939 m. kovą Lietuvos kariuomenès dalys traukèsi spaudžiant SA ir Ordnungsdiensto smogikams, o Klaipėdos krašto „šauliai pasirodè esą netinkami atlikti kovinius uždavinius" ${ }^{182}$ ir buvo nuginkluoti.

Žinoma, dèl Klaipèdos krašto pavienių šaulių nuotaikų ir pasirengimo galima diskutuoti. Dalis XX Klaipèdos rinktinès šaulių išvyko ị Lietuvą ir issitrauke i kitų rinktinių veiklą, tačiau XX rinktinès vadui, $1939 \mathrm{~m}$. vasarą renkant duomenis apie pasitraukiant iš krašto išgabentą rinktinès turtą, pavyko rasti tik 241 šauli, iki to laiko užsiregistravusị kitoje rinktinèje ${ }^{183}$,

\footnotetext{
178 Šaulio H. Bako 1939 m. gegužès 19 d. raportas VI Ukmergès rinktinès vadui. LCVA, f. 561, ap. 2, b. 4550, 1. 52-52 apv. 1.

${ }^{179}$ Kariuomenès štabo II skyrius, žinios iki 1939 m. kovo 22 d. 18 val. LCVA, f. 929, ap. 2, b. $1068,1.9$.

${ }^{180}$ Jēkabsons, Ē. Klaipēdas nonākšana Vācijas varā 1939. gada martā: skats no Latvijas. Latvijas Arhīvi, 2011, Nr.1/2, 1. 124.

${ }^{181}$ Vareikis, V. Klaipėda XX amžiuje. Klaipèda, 1993, p. 41.

182 Ten pat, p. 46.

${ }^{183}$ I rinktinejje - 33 šauliai, III Telšių rinktinèje - 26 šauliai, IV Tauragès - 29, V Trakų 10, VII Šiaulių - 51, Vilkaviškio - 7, X Rokiškio - 5, XI Raseinių - 14, XII Panevèžio - 15,
} 
o tai tik kiek daugiau nei aštuntadalis buvusių rikiuotès šaulių. Žinoma, tai nereiškia, kad tik tiek šaulių 1939 m. kovą pasitraukè iš uostamiesčio, tikètina, kad dalis jų dèl ịvairių priežasčių iki 1939 m. liepos neịsitraukè i kitų rinktinių veiklą.

Klaipėdos kareivinèse liko kuro, pašarų, maisto produktų ir Butų skyriaus turto, kurio išvedimo metu Lietuvos kariuomenè nespejo išvežti ${ }^{184}$, Pagėgiuose - 17000 šovinių, tačiau buvo išvežta patalynè ir kareivių asmeniniai drabužiai ${ }^{185}$. Be to, prarastame uostamiestyje liko ir $22 \mathrm{~d}$. LŠS atsiųstas karinis krovinys - krašto šauliams, iš kurių ginklai nebuvo surinkti, komendantas ji nurode sleppti ${ }^{186}$, taip pat LŠS jachta Šaulys ${ }^{187}$. Taigi išvedimo metu Lietuvos kariuomenè nespejjo išvežti viso savo turto, todèl kovo $24 \mathrm{~d}$. kariuomenès vadas 6-ojo PP mjr. Petrui Buragui pavedè vykti ị Klaipėdą ir rūpintis palikto kariuomenès ir LŠS turto ir ginklų atgabenimu ị Lietuvą, o nesant galimybių arba labai brangiai kainuojant - ji parduoti vietoje $\mathrm{e}^{188}$. Kartu porai savaičiu i Klaipėdą buvo komandiruoti puskarininkiai Kazys Leknickas ir Pilvinis, kurie pagal susitarimą su Vokietija organizavo likusio Klaipedoje kariuomenès turto pargabenimą. Malkos ir pašarai buvo parduoti ${ }^{189}$. I Lietuvą nuo balandžio $28 \mathrm{~d}$. iki gegužès $11 \mathrm{~d}$. buvo išgabenti

XIII Mažeikių - 7, Marijampolès - neužsiregistravo, XV Kretingos - 9, XVI Kèdainių 2, XVII Šakių - 4, XVIII Biržų - 9, XIX Alytaus - 7, XII geležinkelių - 13: Žinios apie XX rinktinès šaulius, užsiregistravusius kitose rinktinèse, 1939 m. birželis-liepa. LCVA, f. 561, ap. 2, b. 4532, 1. 465-492.

${ }^{184}$ III PD vado įsakymas 6-ojo PP vadui. 1939 m. kovo 24 d. LCVA, f. 519, ap. 1, b. 383, 1. 76 .

185 7-ojo PP vado 1939 m. kovo 29 d. įsakymas plk. ltn. Stanuliui. LCVA, f. 520, ap. 1, b. 350, 1. 45.

${ }^{186}$ Klaipėdos krašto komendantūros komendanto $1939 \mathrm{~m}$. balandžio $5 \mathrm{~d}$. raportas III PD vadui. LCVA, f. 929, f. 9, b. 236, 1. 17-18.

${ }^{187} 1937$ m. gegužę LŠS Latvijoje įsigijo sportinę jachtą ir pavadino Šauliu (ilgis 16 m, grimzle $2,1 \mathrm{~m}$, stiebo aukštis $25 \mathrm{~m}$, burių plotas 17,61 $\mathrm{m}^{2}$ ). Jachta (patobulinta ir suremontuota) LŠS kainavo apie 15000 Lt. 1939 m., traukiantis iš Klaipeddos, ji po žiemos dar nebuvo nuleista ị vandenị ir liko. Jachtos išgabenimu rūpinosi P. Buragas, tačiau Vokietija pareikalavo atlikti jos remontą, o šis kainavo apie $1000 \mathrm{RM}$ (arba $2400 \mathrm{Lt}$ ): LŠS vado 1939 m. gegužès 24 d. raportas kariuomenès tiekimo viršininkui. LCVA, f. 832, ap. 1, b. $58,1.212$.

${ }^{188}$ III PD vado iqsakymas 6-ojo PP vadui. 1939 m. kovo 24 d. LCVA, f. 519, ap. 1, b. 383, 1. 76 .

${ }^{189}$ Leknickas, K. 6 pèst. pulko pasitraukimas iš Klaipèdos. Karys, 1964, sausis, Nr. 1 
42 vagonai turto; malkos ir šienas už 3287 reichsmarkes (RM) parduoti, šiaudai liko, be to, dalị turto, tarp viso kito - avižas ir anglis, varžytinėse pardavė magistratas ${ }^{190}$. Jachta Šaulys ị Šventąją iš Klaipėdos atplaukẻ tik 1939 m. liepos 9 d. ${ }^{191} 1939$ m. birželị buvo konstatuota, kad XX rinktiné, pasitraukusi iš Klaipėdos, prarado karinio turto už $218560,69 \mathrm{Lt}$, be viso kito, 990 šautuvų, 8 lengvuosius Maxim 08/15 kulkosvaidžius, 64 revolverius, apie 249000 ịvairių šovinių ${ }^{192}$. Dalis minètų ginklų buvo patekę $\dot{t}$ 6-ąj PP arba i̇ mokomąji karo laivą, tad nebuvo prarasti. Taigi realūs LŠS nuostoliai tokie dideli nebuvo. Štai XX rinktinès Jūros šaulių būrio vadas ats. j. ltn. Juozas Maurukas informavo, kad būrio kasą - 350 litų - tebeturi būrio kasininkas Edvardas Liaupsinas, kuris liko gyventi Klaipèdoje, būrio dokumentai sunaikinti, o 25 šautuvai ir apie 1000 šovinių pateko ị laivą Prezidentas Smetona ${ }^{193}$.

Klaipėdos krašto netektis paskatino Lietuvos kariuomenès dalinius perdislokuoti ir, pasak gen. št. plk. ltn. Juozo Listopadskio, jau naktị iš kovo 23 i 24 d. dalis Klaipėdos iggulos pèsčiomis pasiekė Plungę ${ }^{194}$. Laikinai Kretingoje likę Klaipèdos ịgulos padaliniai ị Plungę atvyko 1939 m. kovo 31 d. 21 val. ${ }^{195}$ Vytautas Lesčius nurodo, kad 6-ojo PP daliniai iš Klaipedos laikinai buvo išdèstyti Kretingoje, o vèliau perkelti ị Plungę, Telšius ir Tryškius. I Plungę buvo perkeltas ir Klaipėdoje buvęs pulko ir Klaipedos krašto komendantūros turtas ${ }^{196}$. Klaipèdoje stovèjęs motorizuotasis artilerijos būrys buvo perduotas 4-ojo AP vado žinion ${ }^{197}$. 6-ojo PP vieną priedangos tipo

(1398), p. 11.

${ }^{190}$ KAM igaliotinio prie Lietuvos Vyriausybès komisaro Klaipėdoje 1939 m. gegužès 13 d. raportas. LCVA, f. 561, ap. 2, b. 4532, 1. 414.

191 Šaulių sąjungos vadas Kariuomenès vadui, 1939-07-10. LCVA, f. 832, ap. 1, b. 58, 1. 215.

${ }^{192}$ XX Klaipėdos rinktinès evakuacijos metu palikto turto sąrašas. $1939 \mathrm{~m}$. birželio $12 \mathrm{~d}$. LCVA, f. 561, ap. 2, b. 4532, 1. 497-498.

${ }^{193}$ XX rinktinès Jūros šaulių būrio vado J. Mauruko 1939 m. birželio 13 d. raportas. LCVA, f. 561, ap. 2, b. 4532, 1. 508.

${ }^{194}$ Listopadskis, J. Laisves ir vergovés metai. Vilnius, 1993, p. 57-58.

195 6-ojo PP vado 1939 m. balandžio 2 d. raportas. LCVA, f. 519, ap. 1, b. 383, 1. 81.

${ }^{196}$ Lesčius, V. Lietuvos kariuomenès organizavimo, dislokavimo ir ginkluotès pokyčiai 1938-1940 m. Karo archyvas, t. XXIV, 2009, p. 131.

${ }^{197}$ III PD 1939 m. kovo 27 d. įsakymas. LCVA, f. 519, ap. 1, b. 383, 1. 79. 
batalioną be kuopos buvo nutarta dislokuoti Plungeje, o vieną kuopą Rietave $^{198}$. Iki tol Plungèje buvęs pulko II batalionas ir artilerijos grupe be vienos baterijos persikèlè $\mathfrak{i}$ Telšius, kur nebuvo tinkamų patalpų ir infrastruktūros ${ }^{199}$. Telšiuose 6-ojo pèstininkų pulko padaliniai, apie 700 žmonių, ìsikūrè amatų, S. Daukanto ir žydų pradžios mokyklose, o sandèliavimui naudojo Lietūkio sandèlius ${ }^{200} .1939$ m. liepos 31 d. Klaipèdos krašto komendantūra buvo išformuota, o dokumentai ir turtas perduoti kitiems daliniams ir įstaigoms ${ }^{201}$. I 7-ąjị PP pasiųstas tankų būrys $1939 \mathrm{~m}$. balandžio 19 d. buvo grąžintas ị savo dalinị Radviliškyje $\mathrm{e}^{202}$.

Vokietija 1939 m. kovo mèn., užimdama Klaipėdos kraštą, iš esmès pasitelkè dalinius, kurie stovejo Rytų Prūsijos teritorijoje: 22-ąji ir 43-iąji PP, 1-ojo korpuso motorizuotuosius dalinius ir karo laivyną ${ }^{203}$. Klaipèdos kraštui užimti Vokietija pasirengė labai kruopščiai. A. Hitleris pasiruošti užimti Klaipèdos kraštą vermachtui nurodè dar 1938 m. spalio mènesị. Karaliaučiuje buvo ịsteigtas štabas, kuris rūpinosi Klaipėdos krašto prijungimo darbais, vyko E. Neumanno ir reicho politikų pasitarimai. Buvo mokomi Klaipedos SA smogikai, o iš Rytų Prūsijos ị kraštą vyko kariniai instruktoriai ${ }^{204} .1939$ m. kovo 22 d. Rytų Prūsijoje prasidejo Vokietijos kariuomenès pergrupavimas ${ }^{205}$, ir prieš Klaipèdos krašto užèmimą Vokietijos kariuomenè buvo sutelkta prie Nemuno, operacijai vykdyti buvo suformuotas štabas, kuris turejjo vadovauti visų rūšių kariuomenei. Parengtos pajėgos numatyta tvarka kovo 22 d., 19.00-21.00 val., peržengé Lietuvos

\footnotetext{
${ }^{198} 1939$ m. balandžio 13 d. protokolas. LCVA, f. 929. ap. 3, b. 1089, 1. 13.

${ }^{199}$ Kariuomenès štabo III skyrius Kariuomenès tiekimo viršininkui Nr. 31869, 1939 m. gegužès 6 d. LCVA, f. 929. ap. 3, b. 1089, 1. 19.

${ }^{200}$ Divizijos vado 1939 m. gegužès 12 d. raportas Karo butų valdybos viršininkui Nr. 3610 . LCVA, f. 384. ap. 2, b. 1069, 1. 144.

${ }^{201}$ Divizijos vado 1939 m. rugpjūčio 10 d. raportas Kariuomenès tiekimo viršininkui Nr. 7365. LCVA, f. 384. ap. 2, b. 1069, 1. 338.

${ }^{202}$ Karo technikos viršininkas Kariuomenès štabo viršininkui Nr. 738, 1939 m. balandžio 24 d. LCVA, f. 929. ap. 3, b. 1089, 1. 14.

${ }^{203}$ Vokietijos karinè veikla 1939 m., 1940 m. gegužès 1 d. LCVA, ap. 2, b. 1084, 1. 16.

${ }^{204}$ Meindl, R. Ostpreußens Gauleiter. Erich Koch - eine politische Biographie. Osnabrück, 2007, S. 241-242.

${ }^{205}$ Truska, L.; Kancevičius, V. Lietuva Stalino ir Hitlerio sanderio verpetuose. Vilnius, 1990 , p. 8.
} 
ir Vokietijos sieną Tilžès tiltu. Pirmieji važiavo smogikų ir SS daliniai su orkestru ir vèliavomis, motorizuotieji kariuomenès daliniai, paskui pèstininkai. Vokietijos kariuomené, palikusi nedideles igulas Pagègiuose ir Šilutėje, traukẻ ił Klaipėdą. Kavalerijos eskadrono dalys žygiavo Vilkyškių link, atvyko viena tankų kuopa. Heinrichas Himmleris su savo štabu, kai kuriais daliniais Klaipėdos geležinkelio stotyje pasirodė kovo 22 d., apie 22.00 val. ${ }^{206}$ Kitą rytą, kovo 23 d., apie 9.00 val., Klaipėdoje pradejjo kaukti fabrikų sirenos ir skambinti bažnyčių varpai ${ }^{207}$. 10.20 val. ị uostą atvyko vokiečių karinis laivynas: kreiseriai Deutschland ir Leipzig, šarvuočiai Graf Spee, Nürnberg, Köln ir Admiral Scheer, minininkai, torpediniai ir išminuoti skirti, taip pat keli povandeniniai laivai ir 3-ioji eskadrinių minininkų flotilè - operacijoje dalyvavo 43 ịvairūs Vokietijos karo laivai. Desanto daliniai atsivežè lengvụjų patrankų ${ }^{208}$. Vokietijos kariuomenès desantą sudarè jūrininkai, desantininkai ir krantų apsaugos dalinių kariai, ginkluoti karabinais. Lietuvos kariuomenès žvalgybos, kuri turẻjo stulbinantį agentų tinklą Vokietijoje $e^{209}$, duomenimis, ị Klaipedą buvo atvykęs 31 karo lai$\operatorname{vas}^{210}$. Karo laivų eskadrą lydejo du karo aviacijos naikintuvų divizionai (apie 30 lèktuvų). Kreiseriu Deutschland atplaukè A. Hitleris ir aukštieji kariuomenès vadai. Uosto gylis buvo nepakankamas didiesiems laivams ịplaukti, todèl A. Hitleriui teko persèsti ị mažesnị torpedinị laivą Leopard, kuris krantą, kur fiurerio laukè išrikiuoti jūrininkų ir kariuomenès daliniai, pasiekè 14.05 val. $^{211}$ Kovo 24 d., Lietuvos kariuomenès štabo II sky-

\footnotetext{
206 Žostautaitè, P. Klaipédos kraštas 1923-1939. Vilnius, 1992, p. 334-335; Vareikis, V. Klaipėdos krašto praradimas: tarp iliuzijų ir Realpolitik. Kultūros barai, 2009, Nr. 4 (533), p. 66.

${ }^{207}$ Vareikis, V. 99 Klaipédos istorijos. Klaipèda, 2008, p. 117.

${ }^{208}$ Liekis, Š. „Laivyno paradas“ ir neįvykusi Klaipėdos okupacija 1938 m. Nežinomi Lietuvos ir Vokietijos santykių puslapiai. Genocidas ir rezistencija, 2004, Nr. 2 (16), p. 163-164. ${ }^{209}$ Vokietijai užverbavus Lietuvos kariuomenès štabo II skyriaus darbuotoją Villų Franką, nuo 1938 m. spalio iki 1939 m. gruodžio vokiečiai susekè 45 agentus, dirbusius Lietuvai: Ильмярв, М. Безмолвная капитуляция. Внешняя политика Эстонии, Латвии и Литвы между двумя войнами и утрата независимости (с середины 1920-х годов до аннексии в 1940). Москва, 2012, с. 250.

${ }^{210}$ Kariuomenès štabo II skyrius. Žinios apie Klaipèdos kraštą 1939 m. kovo 23 d. 13 val. LCVA, f. 929, ap. 3, b. 1095, 1. 34.

211 Žostautaitè, P. Klaipédos kraštas 1923-1939. Vilnius, 1992, p. 337-339.
} 
riaus duomenimis, Smalininkuose ir Viešvilèje buvo Vokietijos 1-ojo PP batalionas, 43-iojo PP padaliniai stovejjo Šiluteje, Pagègiuose ir Klaipėdoje, dviratininkų batalionas iš Tilžès dislokuotas Šiluteje ir Klaipèdoje. Krašte buvo artilerijos, kavalerijos ir kitų dalinių ${ }^{212}$. Lietuvos kariné žvalgyba nustaté, kad kovo 17-18 d. ị Rytų Prūsiją (ị Rezenau buvusius sandèlius) buvo atgabenta apie 300 vagonų amunicijos, iš Pilau kariuomenè nejudèjo, i̇ İsruti papildomų dalinių atgabenta nebuvo. Nors 22-asis ir 43-iasis PP buvo papildyti iki karo meto sudèties, mobilizacija Rytprūsiuose nevy$\mathrm{ko}^{213}$. Apskritai buvo aišku, kad sutelktos Vokietijos pajègos nèra gausios ir vykdyti ofenzyvos Lietuvoje rimtai nebuvo ruoštasi. Praejus kelioms dienoms po Klaipedos praradimo Lietuvos karinė žvalgyba informavo, kad Klaipėdos krašte buvo keli skirtingų pulkų batalionai, dviratininkų, kulkosvaidžių batalionas, įvairios paskirties kuopų ir būrių, kavalerijos pulkas, tankų kuopa ir pan. ${ }^{214}$ Jau 1939 m. kovo 24 d. pavakarę dvi sunkiosios artilerijos grupès, kavalerijos pulkas, 10 šarvuočių, atsiųsti motociklininkai ir dviratininkai, du batalionai pèstininkų grị̌zo ị dislokacijos vietas Rytprūsiuose ${ }^{215}$.

Šešiolika tarpukario metų Klaipėdoje trispalvė virš kareivinių pastatų komplekso 1-ojo korpuso plevèsavo tik Lietuvos kariuomenès bataliono „saugoma“. 1939 m., nors ir nepalankiai, išsisprendè Lietuvos politinè dilema, kaip išsaugoti Klaipėdos kraštą. Kritiniu momentu Lietuvos kariuomenei neteko malšinti SA ir Ordnungsdiensto kovotojų sukilimo Klaipèdos krašte ar susikauti su vermachtu mūšio lauke. Paaiškejjus, kad ị Klaipèdos kraštą iž̌engs Vokietijos reguliarioji kariuomené, Lietuvos pajègos veikẻ pagal jau seniau parengtą planą - traukèsi ị Žemaitiją ir užèmé gynybines pozicijas, tačiau iš dalies dèl šaulių nuginklavimo ir koordinavimo, kurị turejo atlikti vyriausybè, stokos kilo kontrolès mieste ir krašte problema. Laiko buvo mažai, karinè igula Klaipėdoje nebuvo itin gausi, o šauliai ne

${ }^{212}$ Kariuomenès štabo II skyrius. Žinios nuo 1939 m. kovo 24 d. 10 val. iki kovo 25 d. LCVA, f. 929, ap. 3, b. 1095, 1. 35.

${ }^{213}$ Kariuomenès štabo II skyrius. Žinios nuo $1939 \mathrm{~m}$. kovo $22 \mathrm{~d}$. 18 val. iki kovo $23 \mathrm{~d}$. 07.00 val. LCVA, f. 929, ap. 2, b. 1068, 1. 10.

${ }^{214}$ Kariuomenès štabo II skyrius. Žinios nuo 1939 m. kovo 25 d. 10 val. LCVA, f. 929, ap. 2, b. 1068, l. 16.

${ }^{215}$ Vareikis, V. Klaipeddos krašto praradimas: tarp iliuzijų ir Realpolitik. Kultūros barai, 2009, Nr. 4 (533), p. 66. 
tik kad nevykdė numatytų funkcijų - neperèmė miesto kontrolès, bet net nesaugojo komendantūros ir kitų centrinès valdžios įstaigų. Šauliai ar bent jau paskiri jų būriai netalkino ir Lietuvos kariuomenès igulai Klaipėdoje, nepasitrauke kartu, kaip buvo numatyta planuose. Kitas svarbus dalykas, išryškèjęs analizuojant Lietuvos kariuomenès karinius Klaipėdos krašto apsaugos planus, - teritorinès gynybos koncepcijos atsisakymas. Karo, jei Vokietija būtų užpuolusi Lietuvą, atveju tikètis reguliariųjų Lietuvos pajègų pergalès mūšio lauke nebuvo galima, tačiau teritorinè šaulių partizanų kova turèjo būti rezultatyvi. Tačiau Klaipèdos krašto užèmimo atvejis rodo, kad mažųų valstybių teritorinè gynyba gausiai tautinių mažumų ir kitai valstybei lojalių asmenų gyvenamose teritorijose neįmanoma. Tai faktas, kuris negali būti pamirštamas. Ir net jei Lietuva tarpukariu būtų organizavusi masinị gyventojų iš kitų šalies apskričių ị Klaipẻdos kraštą perkèlimą, kol daugumą jų nesudarè lojalūs piliečiai, karinès teritorinès gynybos perspektyvų vis vien ten nebūtų buvę. Sunku, o jei valstybė maža - praktiškai neįmanoma, apginti teritoriją, kurios gyventojų dauguma nenori būti „apginti“, ir apie teritorinę gynybą nèra prasmès net svarstyti. Tokioje teritorijoje galima sukelti tik pilietinị karą, nes sèkmingai teritorinei gynybai, paremtai sukarintų darinių ir partizanine taktika, organizuoti reikia, kad visuomenė būtų homogeniška ir konsoliduota.

\section{IŠVADOS}

Tarpukariu Klaipėdos krašto sociokultūrinis atskirumas, gyventojų sudètis ir jų politinė orientacija ị Vokietiją lèmé, kad Lietuvos kariuomenè susidūrè su teritorijos apginamumo problema, nes dèl vyraujančio vietos gyventojų skeptiško požiūrio ị Lietuvos valstybę nebuvo užtektinai valstybei lojalių asmenų, kad būtų galima formuoti patikimus teritorinius gynybos vienetus. Kompleksas priežasčių lèmè, kad ginkluoto konflikto atveju $\mathrm{XX}$ a. 4-ajame dešimtmetyje Lietuvos kariuomenè vermachtui užpuolus šali planavo atsitraukti ir aktyvius gynybos veiksmus pradėti Žemaitijoje, kur būtų sulaukta tiek civilių vietos gyventojų, tiek sukarintų struktūrų 
narių palaikymo ir paramos.

Klaipėdos krašto specifika lèmė, kad asimetrinio karo atveju Lietuva negalejo taikyti pasirinktos gynybos strategijos - stabdyti priešo plačiuose baruose manevruodama ir kartu pradèti partizaninị karą priešo užimtoje teritorijoje, todèl ir 1939 m. kovą susidarius kritinei situacijai karinė vadovybė vadovavosi ịprastais Lietuvos kariuomenei karybos metodais ir pajègas ruošè kovoti tomis sąlygomis, kurioms jos buvo rengiamos. Apskritai Lietuvos kariuomenès pajègų išvedimas iš Klaipèdos krašto, nors ir skubotas, atsižvelgiant ị susidariusią padètị, vis dèlto vyko gana koordinuotai.

Kilus krizei, Lietuvos kariuomenè rengèsi galimam Vokietijos karinių pajègu i̇siveržimui ne tik į Klaipèdos kraštą, kurị apleisti nusprende politiné šalies vadovybė, bet ir ị likusią valstybès teritoriją. Šiame kontekste išskirtini šie Lietuvos kariuomenès veiksmai: karinių dalinių stiprinimas didinant karių skaičių, siunčiant tankų padalinius; iš Klaipèdos ị Kretingą atitraukiant mobilizacijos centrą su visu turtu; skelbiant šalyje slaptą mobilizaciją; dèl nepatikimumo paleidžiant šauktinius karius, kilusius iš Klaipẻdos krašto, kurie nenorejo tarnauti Lietuvos kariuomenėje; daliniuose skelbiat kovinę parengtị. Reaguoti ị kylančią grèsmę pradèta dar gerokai iki Vokietijos ultimatumo, o tai rodo, kad turèta žvalgybinès informacijos, taip pat analitinị požiūrị, kritišką realistinị padèties vertinimą ir parengtị veikti. Vertinant objektyviai, Lietuvos kariuomenė negalejjo apginti Klaipėdos krašto, nes kilus karui su Vokietija Klaipėdos krašte jau pirmosiomis valandomis būtų kilęs dalies vietos gyventojų ir iš Rytų Prūsijos slapta atsiųstų asmenų ginkluotas pasipriešinimas Lietuvos kariuomenei, taip tarptautinei bendruomenei sudarant sukilimo ar net pilietinio karo foną, o Vokietijos pajégoms - pasiteisinimą, kad ịsiveržta ị Lietuvą dèl civilių vokiečių kilmès asmenų apsaugos. 


\title{
SANTRUMPŲ SĄRAŠAS
}

\author{
AP - artilerijos pulkas \\ $\mathrm{KP}$ - kavalerijos pulkas \\ LŠS - Lietuvos šaulių sąjunga \\ $\mathrm{PAB}$ - pasienio apsaugos batalionas \\ PD - péstininkų divizija \\ $P P$ - pėstininkų pulkas \\ $\mathrm{RAB}$ - raitosios artilerijos baterija \\ SA - vok. Sturmabteilung (smogikų būriai) \\ SAP - sunkiosios artilerijos pulkas \\ ŠR - šarvuočių rinktinè
}

Iteikta $2015 \mathrm{~m}$. spalio $28 \mathrm{~d}$. 


\title{
LE RETRAIT DE L'ARMEE LITUANIENNE DE LA REGION DE KLAIPEDA (1939)
}

\author{
Dr. Vytautas Jokubauskas \\ Université de Klaipéda
}

Larticle analyse le retrait de l'armée lituanienne de la région de Klaipèda en mars 1939 en réaction à la crise sécuritaire après l'ultimatum de l'Allemagne. De même, il présente la situation ethnique et politique de la région pendant l'entre-deux-guerres, la confrontation permanente entre l'État lituanien et une partie des habitants de la région de Klaipeda, les circonstances de la présentation de l'ultimatum de l'Allemagne ainsi que le déroulement des opérations des unités militaires lituaniennes en mars 1939. Pendant l'entre-deux-guerres, la région de Klaipeda a appartenu de facto à la République de Lituanie de 1923 à 1939 lorsque l'Allemagne s'est emparée d'un territoire qui lui appartenait jusqu'à la signature du Traité de Versailles en 1919.

Les relations d'une partie des habitants de Klaipeda avec les institutions du pouvoir central de l'État lituanien et l'armée étaient tendues, il y avait en permanence des rumeurs d'insurrection ou de coup d'État imminent. Une partie de la société, qui avait une attitude anti-lituanienne et s'orientait vers l'Allemagne, appartenait à des organisations nazies locales. Un des soutiens de la Lituanie dans la région de Klaipèda était l'Union des francs-tireurs de Lituanie, mais en 1938-1939 l'action de cette organisation est devenue compliquée car une partie des francs-tireurs évitaient de participer à toute activité de l'Union. Une partie des francs-tireurs appartenaient en même temps aux organisations séparatistes allemandes.

Après l'ultimatum de l'Allemagne, le Gouvernement lituanien a pris la décision de retirer ses forces armées de la région de Klaipėda. Parallèlement, une mobilisation secrète a été effectuée en Lituanie, les unités militaires ont été complétées avec des réservistes et les biens nécessaires à l'armée réquisitionnés. Les unités frontalières ont été renforcées par l'envoi d'unités de chars. Il y a eu de la confusion dans les garnisons de la région 
de Klaipèda en raison de la précipitation et de la nécessité de désarmer les francs-tireurs, membres d'une organisation paramilitaire. Toutefois, les unités de l'armée lituanienne se sont retirées en emportant presque tous ses biens et en évitant des incidents mortels. 


\title{
WITHDRAWAL OF THE LITHUANIAN ARMY FROM KLAIPĖDA REGION (1939)
}

\author{
Dr Vytautas Jokubauskas \\ Klaipèda University
}

The article analyses the withdrawal of Lithuanian troops from Klaipeda region in 1939 as a reaction to the security crisis after the German ultimatum, the national and political situation in the land during the interwar period, the permanent confrontation between the state of Lithuania and the population of Klaipeda region, the circumstances of submitting to the German ultimatum and the course of action of Lithuanian military units in March 1939. During the interwar period, from 1923 to 1939, when Klaipeda region belonged de facto to the Republic of Lithuania, Germany invaded the territory that belonged to it until 1919 when the Versailles Peace Treaty was signed.

Relations between the population of Klaipeda region, the central authorities of Lithuania and the army during the interwar period were tense; there were rumours about imminent uprisings and coups. Some of the antiLithuanian society was focused on Germany and belonged to local German national socialist organisations. One supporting organisation in Klaipeda region was the Lithuanian Riflemen's Union. However, in 1938-1939, the activity of this organisation became more complicated because some of the riflemen avoided participating in any activities of the Union. Some of the riflemen belonged to German separatist organisations at the same time.

After receipt of the German ultimatum, the Lithuanian government decided to withdraw its military forces from the Klaipeda region. In parallel, secret mobilisation was carried out in Lithuania and military units were supplemented with reservists, and property necessary to the army was requisitioned. Border units were strengthened with additional tank units. Confusion erupted amongst the military units of Klaipeda region because of the urgent need to disarm the members of the paramilitary organisation the riflemen. However, the Lithuanian army units retreated and took with them almost all of their assets, and avoided any fatal incidents. 